\title{
Effects of Effluent Spray Irrigation and Sludge Disposal on Ground Water in a Karst Region, Northwest Pinellas County, Florida
}

By John T. Trommer

U.S. GEOLOGICAL SURVEY

Water-Resources Investigations Report 91-4181

Prepared in cooperation with

PINELLAS COUNTY, FLORIDA 


\section{U.S. DEPARTMENT OF THE INTERIOR \\ MANUEL LUJAN, JR., Secretary}

U.S. GEOLOGICAL SURVEY

DALLAS L. PECK, Director

For additional information, write to:

District Chief

U.S. Geological Survey

Suite 3015

227 North Bronough Street

Tallahassee, Florida 32301
Copies of this report may be purchased from:

U.S. Geological Survey

Books and Open-File Reports Section Federal Center

Box 25425

Denver, Colorado 80225 


\title{
CONTENTS
}

\author{
Abstract 1 \\ Introduction 1 \\ Purpose and scope 3 \\ Previous investigations $\mathbf{3}$ \\ Acknowledgments $\mathbf{3}$ \\ Approach 3 \\ Description of the study area 7 \\ Topography and drainage 7 \\ Hydrogeology 9 \\ Predisposal ground-water flow system 12 \\ Background water quality 13 \\ Disposal operations 13 \\ Effects of effluent spray irrigation and sludge disposal $\quad 15$ \\ Ground-water levels and flow system 15 \\ Water quality 17 \\ Initial water-quality results 18 \\ Distribution of water-quality constituents in the surficial aquifer $\mathbf{2 0}$ \\ Distribution of water-quality constituents in the Upper Floridan aquifer 26 \\ Summary and conclusions $\mathbf{3 1}$ \\ Selected references $\mathbf{3 2}$
}

\section{FIGURE}

1. Map showing location of Pinellas County, the study site, treatment plant, and disposal site prior to $1988 \quad 2$

2. Map showing location of data-collection sites and traces of geologic sections $A-A^{\prime}$, $B-B^{\prime}$, and $C-C^{\prime}$, and hydrogeologic sections $D-D^{\prime}$ and $E-E^{\prime} \quad 4$

3. Ground-penetrating radar record showing cross-bedded surficial deposits at the study site 7

4. Map showing topography of the study area prior to $1988 \mathbf{8}$

5. Geologic sections $A-A^{\prime}, B-B^{\prime}$, and $C-C^{\prime} \quad 10$

6. Ground-penetrating radar record showing the irregular surface of the underlying sediments at the study site 12

7. Map showing the configuration of the water table of the surficial aquifer prior to disposal operations, September $1974 \quad 13$

8. Map showing location of treatment plant and disposal site after $1988 \quad 15$

9. Hydrographs of water levels in the surficial and Upper Floridan aquifer wells in 1988 indicating small head difference and similar water-level fluctuations $\mathbf{1 6}$

10. Maps showing configuration of the water table of the surficial aquifer and direction of ground-water flow, May and September 198817

11. Maps showing configuration of the potentiometric surface of the Upper Floridan aquifer and the direction of ground water flow, May and September $1988 \quad 18$

12. Graphs showing specific conductance and chloride concentrations of water from the surficial aquifer and Upper Floridan aquifer at well site 38, 1974-89 20

13. Map showing specific conductance of water from the surficial aquifer, March and April 198923

14. Diagram showing specific conductance of ground water along hydrogeologic sections $D-D^{\prime}$ and $E-E^{\prime} \quad 24$ 
15. Map showing distribution of sodium and chloride concentrations in water from the surficial aquifer, March and April 198925

16. Map showing distribution of nitrate-nitrogen concentration and the nitrogen isotope ratio in water from the surficial aquifer, March and April 198925

17. Map showing distribution of methylene blue active substance in water from the surficial aquifer, March and April 198926

18. Trilinear plot of major cation and anion equivalent concentration percentages 28

19. Graph showing conductivity profile of water in the Upper Floridan aquifer well at site 19, September 1988 and March 198929

20. Map showing distribution of nitrate-nitrogen concentration and the nitrogen isotope ratio in water from the Upper Floridan aquifer, March and April 198930

21. Map showing distribution of methylene blue active substance in water from the Upper Floridan aquifer, March and April $1989 \quad 32$

\section{TABLE}

1. Data-collection sites $\mathbf{5}$

2. Hydrogeologic framework 11

3. Summary of selected background water-quality data 14

4. Summary of selected water-quality data for samples from the effluent holding pond 16

5. Selected long-term water-quality data for wells at site $38 \quad 19$

6. Summary of selected water-quality data for sites in the surficial and Upper Floridan aquifers, 1987-88 21

7. Summary of selected water-quality data for sites in the surficial aquifer, March and April 198922

8. Summary of selected water-quality data for sites in the Upper Floridan aquifer, March and April 198927 
Conversion Factors, Vertical Datum, Abbreviated Water-Quality Units, and Acronyms

\begin{tabular}{lcl}
\hline \multicolumn{1}{c}{ Multiply } & By & \multicolumn{1}{c}{ To obtain } \\
\hline inch (in.) & 25.4 & millimeter \\
inch per year (in/yr) & 2.54 & centimeter per year \\
foot (ft) & 0.3084 & meter \\
foot per day (ft/d) & 0.3084 & meter per day \\
foot squared per day $\left(\mathrm{ft}^{2} / \mathrm{d}\right)$ & 0.09290 & square meter per day \\
cubic foot per second $\left(\mathrm{ft}^{3} / \mathrm{s}\right)$ & 0.02832 & cubic meter per second \\
acre & 0.004047 & square kilometer \\
square mile (mi ${ }^{2}$ ) & 2.590 & square kilometer \\
million gallons (Mgal) & 3,785 & cubic meter \\
million gallons per day & 0.04381 & cubic meter per second \\
$\quad$ (Mgal/d) & & cubic meter \\
billion gallons (Ggal) & $3,785,000$ & cubic meters per year \\
billon gallons per year & $3,785,000$ & kilogram per hectare \\
$\quad$ (Ggal/yr) & & \\
pound per acre (lb/acre) & 1.836 &
\end{tabular}

Temperature in degrees Fahrenheit $\left({ }^{\circ} \mathrm{F}\right)$ may be converted to degrees Celsius $\left({ }^{\circ} \mathrm{C}\right)$ as follows: ${ }^{\circ} \mathrm{C}=5 / 9 \times\left({ }^{\circ} \mathrm{F}-32\right)$.

Sea level: In this report, "sea level" refers to the National Geodetic Vertical Datum of 1929 (NGVD of 1929) - a geodetic datum derived from a general adjustment of the first-order level nets of the United States and Canada, formerly called Sea Level Datum of 1929.

Abbreviated water-quality units:

$\mu \mathrm{g} / \mathrm{L} \quad$ micrograms per liter

$\mu \mathrm{S} / \mathrm{cm}$ microsiemens per centimeter

$\mathrm{mg} / \mathrm{L}$ milligrams per liter

ppt parts per thousand

Acronyms:

GPR ground penetrating radar

MBAS methylene blue active substance

VOC volatile organic compound 


\title{
Effects of Effluent Spray Irrigation and Sludge Disposal on Ground Water in a Karst Region, Northwest Pinellas County, Florida
}

\author{
By John T. Trommer
}

\section{ABSTRACT}

Pinellas County, Florida, has been disposing of sludge and secondary treated sewage since 1976 at a 3-milliongallon-per-day treatment plant and disposal site in the northwestern part of the county. Approximately 1.1 billion gallons of effluent are disposed of annually at the site and at an adjacent golf course.

A discontinuous clayey residuum layer separates the surficial aquifer from the limestone of the Upper Floridan aquifer at the site. A high degree of secondary porosity apparently exists in the limestone throughout the central part of the study area, creating a ground-water trough in both aquifers. As a result of disposal operations, mounding of ground water occurs in the surficial aquifer under the disposal site and the golf course. A ground-water mound also is present in the Upper Floridan aquifer under the disposal site during onsite disposal.

The most significant effect on ground-water quality in the vicinity of the disposal site is high nitrate-nitrogen concentrations that exceed 10 milligrams per liter. Stable nitrogen isotope analyses indicate that wells west of the disposal site contain water with nitrate-nitrogen concentrations that indicate an animal (human) source of the concentrations, probably originating from the effluent. Other water-quality constituents showed increased concentrations, but were within the limits allowed for potable supply. Water-quality problems in some Upper Floridan aquifer wells south of the disposal site are due to the influence of saltwater.

\section{INTRODUCTION}

Since 1976, Pinellas County has been disposing of treated sewage by spray irrigation and periodic land spreading of dried sludge at a 118 -acre wastewater treatment and disposal facility, commonly referred to as the North Plant, in the northwest part of the county (fig. 1). Land application of secondary treated municipal sewage (1) allows for further treatment by natural filtration and biochemical processes, thereby providing an alternative to expensive advanced treatment; (2) provides additional ground-water recharge; and (3) when used for irrigation purposes, lowers the demand for water from the Upper Floridan aquifer in a rapidly developing area that is already affected by saltwater encroachment (Heath and Smith, 1954). This disposal method also is consistent with Pinellas County's policy of zero discharge of wastewater to shallow coastal waters.

Although there are advantages to land application of treated sewage, the practice may have potential problems (Johnson, 1979). Secondary sewage treatment reduces the levels of suspended solids and some pathogenic microorganisms; however, high concentrations of nutrients, trace metals, and some organic compounds, such as chloroform and vinylchloride, remain. If the application rates of the sprayed effluent exceed the capacity of the vegetation or soils to utilize or adsorb these compounds, they may percolate downward into the ground water.

Within the study area, the Upper Floridan aquifer is thinly covered and, in places, is in direct hydraulic connection with the overlying surficial sands. The aquifer is the primary source of drinking water for a small population residing to the south and west of the disposal site. In 1990, county water mains were extended to this area, providing a permanent source of potable water to the residents. The Upper Floridan aquifer also is the source of water that discharges from Wall Springs, formerly a private swimming and recreational area along the coast about 2,000 ft west of the disposal site. In 1988, Wall Springs was purchased by the Pinellas County Parks Department for future redevelopment as a recreational area.

Monitoring wells at the disposal site and selected private supply wells outside the site have been sampled periodically for nutrients and some metals since 1970. Data from these analyses indicate that water-quality problems exist in some wells south of the site and that concentrations of nutrients and some inorganic constituents in wells west of the site and in Wall Springs are increasing. The overall effects of disposal operations on the surrounding environment, however, have not been evaluated. To assess the effects of effluent-spray irrigation and sludge disposal on the groundwater quality in the vicinity of the sewage-treatment plant, the U.S. Geological Survey and Pinellas County began a cooperative study in 1987. 


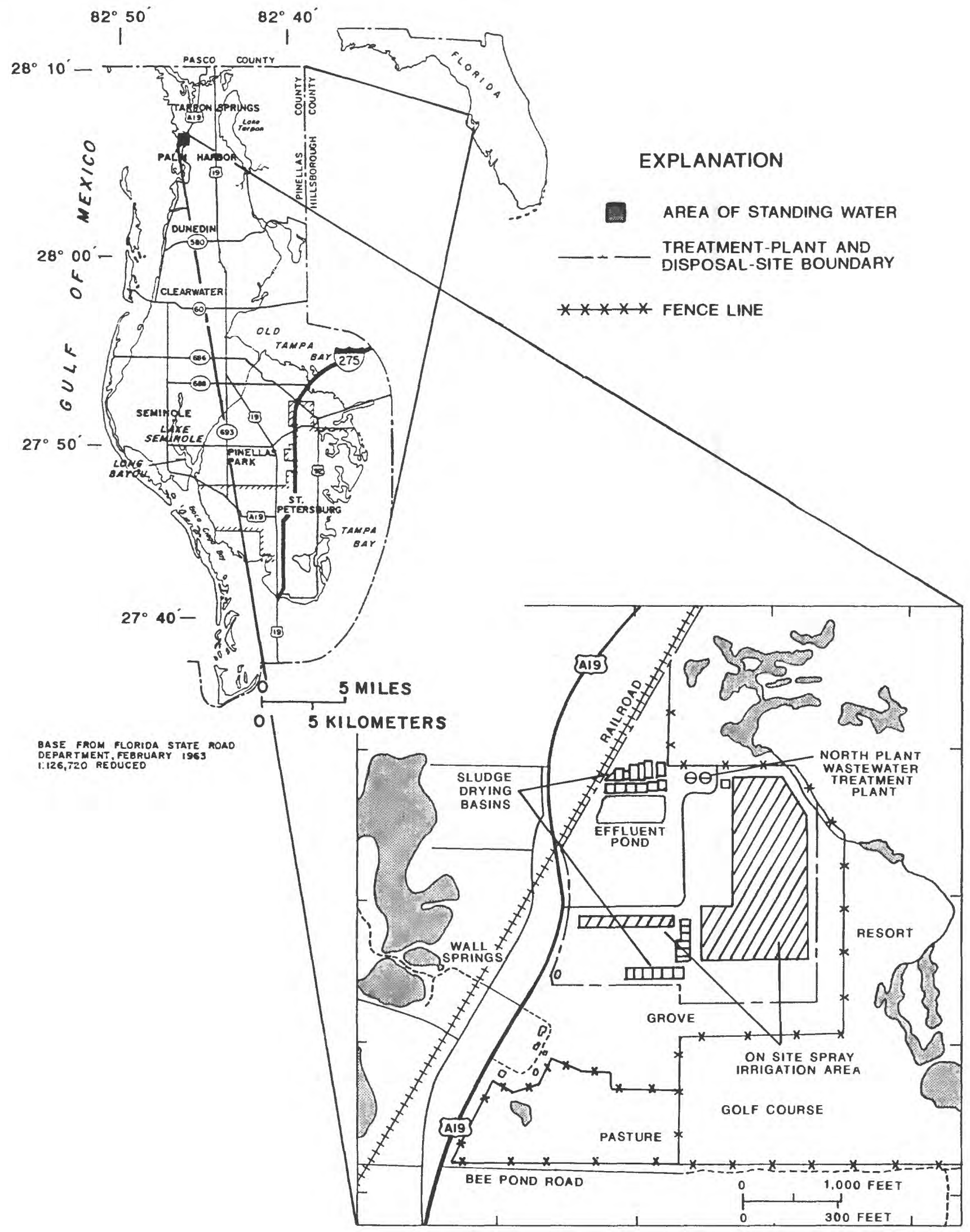

Figure 1. Location of Pinellas County, the study site, treatment plant, and disposal site prior to 1988. 


\section{Purpose and Scope}

This report describes the effects of effluent spray irrigation and sludge disposal on ground water in the vicinity of the North Plant sewage-treatment and disposal site in northwestern Pinellas County. The specific objectives of the study were to determine (1) the extent to which effluent and sludge disposal operations have affected the quality of the ground water at and downgradient from the disposal site; and (2) if fertilizer, herbicides and insecticides, and effluent applied at a resort east of the disposal site are moving through the ground-water system into the site.

Information contained in this report is based on data collected within a 1- $\mathrm{mi}^{2}$ area during the study period (October 1986 through September 1990), from historical data in the files of the U.S. Geological Survey and Pinellas County, and from previously published reports. This report contains data on 79 wells, 4 surface-water sites, and 1 spring in the vicinity of the disposal site. Data compiled and analyzed in this report include water-level measurements, water quality, aquifer properties, and lithologic descriptions from drillers' logs and from cores collected during drilling operations. Groundpenetrating-radar (GPR) surveys were used to supplement the drilling data and to further define the hydrogeology at the study site.

\section{Previous Investigations}

Previous reports by the U.S. Geological Survey and the Florida Geological Survey have described the hydrogeology and quality of water within the surficial and Floridan aquifer systems in Pinellas County. Heath and Smith (1954) investigated the ground-water resources of Pinellas County, and Cherry (1966) discussed chloride concentrations in ground water and saltwater encroachment in the county. Cherry and others (1973) discussed the hydrobiochemical effects of spraying waste-treatment-plant effluent in St. Petersburg, and Brown (1981) investigated a treated-effluent disposal test site at a resort adjacent to the present sewage-treatment plant. Hickey (1982) discussed the hydrogeology and aquifertest results of proposed injection sites in Pinellas County, Although the disposal site was included in the study (Hickey, 1982), the study concentrated on the deeper formations in the Floridan aquifer system. Causseaux (1985) studied the surficial aquifer of Pinellas County, but specific data generally were not available for the area around the disposal site.

\section{Acknowledgments}

The author gratefully acknowledges the many individuals who gave their assistance and cooperation in conjunction with this investigation, particularly the personnel of the
Pinellas County Sewer System Monitoring Laboratory and the operators of the North Plant wastewater-treatment facility. Special thanks are extended to the Douglas family for allowing access to their property for drilling and monitor-well installation and to all property owners in the area who allowed access to the wells used for water-quality sampling during the study.

\section{Approach}

An inventory of existing wells in the study area was conducted to establish a preliminary monitoring network. Subsequently, Wall Springs, the effluent holding pond (fig. 1), 3 surface-water sites, and 35 additional wells that were drilled during the study period were included to complete the monitoring network. The location of data-collection sites in the network are shown in figure 2. Map numbers, identification numbers, depths of wells, and aquifers tapped are presented in table 1.

Hydrogeologic conditions at the study site were determined from previously published lithology and aquifer data for similar adjacent areas and from drilling data that were collected during the study period. Hydraulic conductivity values (a measure of the ability of an aquifer to transmit water) for the surficial aquifer and semiconfining bed were determined from laboratory analysis of split-spoon samples collected at the disposal site. Samples were analyzed by the University of South Florida, Department of Geology, Tampa, Fla., using a constant head permeameter. Additional mineralogic analyses were performed by the U.S. Geological Survey, Reston, Va. (McCarten and others, 1992). Geologic sections were constructed from lithologic logs of selected test wells and were supplemented by GPR surveys run between well sites. Fifteen water-level measurements were collected from surficial and Upper Floridan aquifer wells between 1987 and 1989. Measurements were made to the nearest hundredth of a foot using a steel tape and referenced to sea level. Potentiometric-surface and water-table maps were prepared from the May and September 1988 data and were used to determine the direction of ground-water flow at the end of the spring dry season and the end of the summer wet season.

Available water-quality data were compiled from the files of the U.S. Geological Survey and the Pinellas County Sewer System Monitoring Laboratory and were used to establish background water-quality conditions. Water-quality samples were collected in 1987 and 1988 to determine which constituents could be used as indicators of effluent movement. These samples were analyzed for major ions, nutrients, trace metals, methylene blue active substance (MBAS), and organic compounds. In 1989, water-quality samples were collected to delineate areas that may have been affected by disposal operations. Analyses of these samples included 


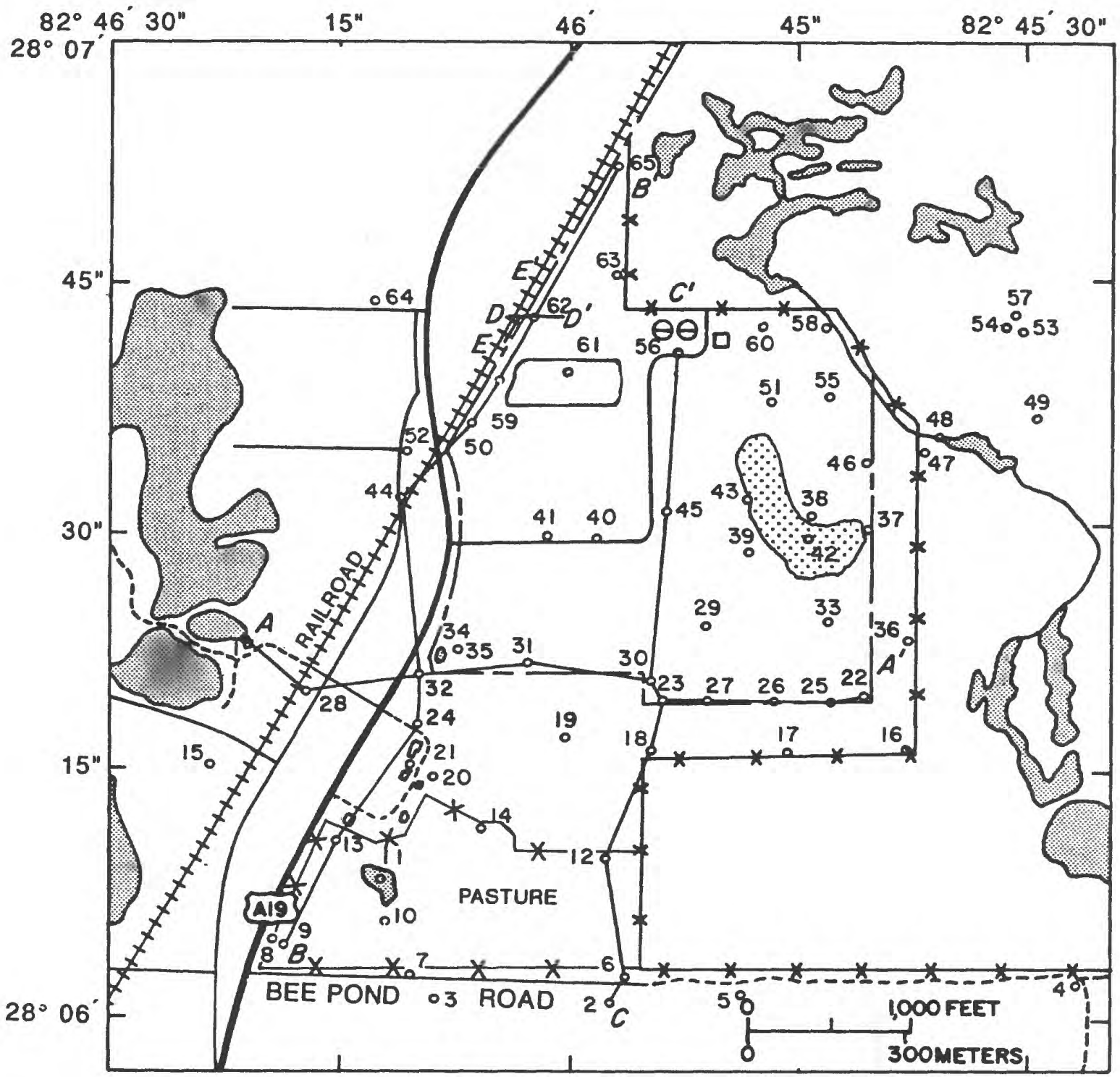

EXPLANATION

AREA OF STANDING WATER

SEASONALLY PONDED AREA PRIOR TO 1988

A $A^{\prime}$ TRACE OF GEOLOGIC OR HYDROGEOLOGIC SECTION

- - TREATMENT-PLANT AND DISPOSAL-SITE BOUNDARY

$* * *$ FENCE LINE

$18^{\circ}$ DATA-COLLECTION SITE AND MAP NUMBER (see table 1)

Figure 2. Location of data-collection sites and traces of geologic sections $A-A^{\prime}, B-B^{\prime}$, and $C-C$, and hydrogeologic sections $D-D^{\prime}$ and $E-E^{\prime}$. 
major ion, nutrient, and MBAS concentrations and stable nitrogen isotope ratio determinations. The isotope determinations were used to indicate the source of nitrogen at the site. Most water-quality samples were collected using a peristaltic or centrifugal pump. Samples to be analyzed for volatile organic compounds (VOC) were collected using a stainless steel bladder pump or bailer to minimize degassing. All wells were purged until $\mathrm{pH}$ and specific conductance stabilized, or for a minimum of three borehole volumes. All samples were treated with prescribed preservatives and chilled before being sent to the laboratory for analysis. Temperature, specific conductance, $\mathrm{pH}$, and alkalinity were measured in the field at the time samples were collected. Standard methods for data collection and analysis, as described in the "Techniques of Water-Resources Investigations of the U.S. Geological Survey" manuals, were used wherever applicable. Changes and long-term trends were determined by comparison of historical and current water-quality data.

Table 1. Data-collection sites

[-, no data]

\begin{tabular}{|c|c|c|c|c|c|}
\hline $\begin{array}{l}\text { Map } \\
\text { No. }\end{array}$ & Identification No. & Name & $\begin{array}{c}\text { Well } \\
\text { depth } \\
\text { (feet } \\
\text { below } \\
\text { land } \\
\text { surface) }\end{array}$ & $\begin{array}{l}\text { Casing } \\
\text { depth } \\
\text { (feet } \\
\text { below } \\
\text { land } \\
\text { surface) }\end{array}$ & Site type or aquifer \\
\hline 1 & 02309494 & Wall Springs (NS17) & - & - & Spring \\
\hline 2 & 280601082455301 & 1020 BPND FLRD well & - & - & Upper Floridan \\
\hline 3 & 280601082460301 & 810 BPND FLRD well & - & - & Upper Floridan \\
\hline 4 & 280602082453601 & PinCo monitor well NP109 & 41.0 & 11.0 & Surficial \\
\hline 5 & 280603082454601 & USGS NRSD well 0346 & 21.8 & 16.8 & Surficial \\
\hline 6 & 280603082455301 & PinCo monitor well NP108 & 53.0 & 33.0 & Surficial \\
\hline 7 & 280603082461201 & USGS NRSD well 0312 & 23.0 & 18.0 & Surficial \\
\hline 8 & 280604082461701 & PinCo monitor well NP107 & 10.0 & 5.0 & Surficial \\
\hline 9 & 280606082461901 & Douglas pasture west FLRD well & 31.3 & 21.8 & Upper Floridan \\
\hline 10 & 280607082461101 & Douglas pasture 2" NRSD well & 6.0 & 5.0 & Surficial \\
\hline 11 & 280608082461300 & Douglas pasture pond & - & - & $\begin{array}{l}\text { Surface } \\
\text { water }\end{array}$ \\
\hline \multirow[t]{2}{*}{12} & 280611082455601 & Douglas pasture east FLRD well & 76.1 & 66.1 & Upper Floridan \\
\hline & 280611082455602 & USGS NRSD well DP3 & 36.5 & 31.5 & Surficial \\
\hline 13 & 280611082461501 & USGS NRSD well DP1 & 17.3 & 12.3 & Surficial \\
\hline 14 & 280613082460501 & USGS NRSD well DP2 & 12.2 & 7.2 & Surficial \\
\hline 15 & 280614082462301 & 604 Hills FLRD well & - & - & Upper Floridan \\
\hline 16 & 280616082453601 & USGS NRSD well DG3 & 35.5 & 30.5 & Surficial \\
\hline 17 & 280616082454501 & USGS NRSD well DG2 & 43.8 & 38.8 & Surficial \\
\hline 18 & 280616082455401 & USGS NRSD well DGI & 23.8 & 18.8 & Surficial \\
\hline \multirow[t]{2}{*}{19} & 280616082460301 & $\begin{array}{l}\text { Douglas grove irrigation } \\
\text { FLRD well }\end{array}$ & 123.0 & 58.0 & Upper Floridan \\
\hline & 280616082460302 & USGS NRSD well 1603 & 19.6 & 14.6 & Surficial \\
\hline 20 & 280616082460801 & PinCo monitor well NS16 & 28.0 & 22.0 & Surficial \\
\hline 21 & 280616082461001 & Douglas house FLRD well & 40.0 & - & Upper Floridan \\
\hline 22 & 280617082453801 & USGS NRSD well 21 & 23.0 & 22.0 & Surficial \\
\hline 23 & 280618082454001 & USGS NRSD well 31 & 27.5 & 23.0 & Surficial \\
\hline \multirow[t]{2}{*}{24} & 280618082461001 & Douglas grove front FLRD well & 60.0 & - & Upper Floridan \\
\hline & 280619082461001 & $\begin{array}{l}\text { Douglas grove front NRSD } \\
\text { well }(1910)\end{array}$ & 15.8 & 11.0 & Surficial \\
\hline 25 & 280619082454301 & USGS NRSD well 1943 & 31.9 & 26.9 & Surficial \\
\hline \multirow[t]{3}{*}{26} & 280619082454601 & $\begin{array}{l}\text { USGS surficial test \#3 FLRD } \\
\text { monitor well }\end{array}$ & 60.0 & 55.0 & Upper Floridan \\
\hline & 280619082454602 & $\begin{array}{l}\text { USGS surficial test \#3 NRSD } \\
\text { monitor well }\end{array}$ & 43.6 & 37.6 & Surficial \\
\hline & 280619082454603 & $\begin{array}{l}\text { USGS NRSD surficial test } \\
\text { well \#3 }\end{array}$ & 40.7 & 30.7 & Surficial \\
\hline 27 & 280619082455101 & USGS NRSD well 1951 & 34.8 & 29.8 & Surficial \\
\hline 28 & 280620082461701 & USGS FLRD well 2017 & 15.9 & 12.9 & Upper Floridan \\
\hline 29 & 280622082454705 & USGS NRSD well 19.5 & 20.0 & 18.5 & Surficial \\
\hline 30 & 280622082455401 & USGS NRSD well 2254 & 22.8 & 17.8 & Surficial \\
\hline 31 & 280622082460205 & USGS NRSD well 20.5 & 23.0 & 20.0 & Surficial \\
\hline
\end{tabular}


Table 1. Data-collection sites-Continued

\begin{tabular}{|c|c|c|c|c|c|}
\hline $\begin{array}{l}\text { Map } \\
\text { No.' }\end{array}$ & Identification No. & Name & $\begin{array}{c}\text { Well } \\
\text { depth } \\
\text { (feet } \\
\text { below } \\
\text { land } \\
\text { surface) }\end{array}$ & $\begin{array}{l}\text { Casing } \\
\text { depth } \\
\text { (feet } \\
\text { below } \\
\text { land } \\
\text { surface) }\end{array}$ & Site type or aquifer \\
\hline \multirow[t]{2}{*}{32} & 280622082460701 & PinCo monitor well NP106 & 15.1 & 8.0 & Surficial \\
\hline & 280622082460702 & USGS FLRD monitor well 106A & 34.1 & 24.1 & Upper Floridan \\
\hline 33 & 280623082454301 & USGS NRSD well 18.6 & 21.4 & 16.4 & Surficial \\
\hline 34 & 280623082460500 & Sinkhole near well 10 & - & - & Surface water \\
\hline 35 & 280623082460501 & USGS NRSD well 10 & 7.0 & 6.0 & Surficial \\
\hline 36 & 280624082453501 & PinCo monitor well NP105 & 37.0 & 17.0 & Surficial \\
\hline \multirow[t]{4}{*}{37} & 280625082453801 & USGS NRSD well 16.1 & 3.0 & 2.0 & Surficial \\
\hline & 280625082453802 & USGS NRSD well 16.2 & 6.5 & 5.0 & Surficial \\
\hline & 280625082453803 & USGS NRSD well 16.3 & 9.0 & 8.0 & Surficial \\
\hline & 280625082453804 & USGS NRSD well 16.4 & 11.7 & 10.0 & Surficial \\
\hline \multirow[t]{4}{*}{38} & 280629082454202 & USGS NRSD well $20 \mathrm{~B}$ & 6.0 & 5.0 & Surficial \\
\hline & 280629082454203 & USGS NRSD well $20 \mathrm{C}$ & 7.5 & 6.0 & Surficial \\
\hline & 280629082454204 & USGS NRSD well 20D & 12.0 & 11.0 & Surficial \\
\hline & 280629082454205 & USGS FLRD well $20 \mathrm{E}$ & 27.1 & 23.0 & Upper Floridan \\
\hline 39 & 280629082454701 & USGS FLRD well 2947 & 34.6 & 24.6 & Upper Floridan \\
\hline 40 & 280629082455801 & USGS NRSD well 2958 & 44.3 & 38.3 & Surficial \\
\hline 41 & 280629082460101 & USGS FLRD well 2901 & 59.8 & 49.8 & Upper Floridan \\
\hline 42 & 280630082454300 & Lake at PinCo sprayfield & - & - & Surface water \\
\hline 43 & 280631082454601 & $\begin{array}{l}\text { Northwest Pinellas injection } \\
\text { monitor well (24) }\end{array}$ & 12.0 & - & Surficial \\
\hline 44 & 280631082461001 & USGS NRSD well 3110 & 20.1 & 15.1 & Surficial \\
\hline \multirow[t]{3}{*}{45} & 280632082455001 & $\begin{array}{l}\text { Northwest Pinellas Injection } \\
\text { monitor FLRD well }\end{array}$ & 96.0 & 83.0 & Upper Floridan \\
\hline & 280632082455002 & USGS NRSD well 41 & 20.0 & 19.0 & Surficial \\
\hline & 280632082455003 & USGS NRSD test well I & 27.2 & 12.2 & Surficial \\
\hline \multirow[t]{3}{*}{46} & 280633082454001 & USGS test 2 FLRD monitor well & 32.5 & 27.7 & Upper Floridan \\
\hline & 280633082454002 & USGS test 2 NRSD monitor well & 15.2 & 10.2 & Surficial \\
\hline & 280633082454003 & USGS NRSD test well 2 & 17.1 & 7.1 & Surficial \\
\hline \multirow[t]{2}{*}{47} & 280634082453404 & Innisbrook NRSD well 3434.4 & 14.5 & 13.0 & Surficial \\
\hline & 280634082453405 & Innisbrook NRSD well 3434.5 & 19.8 & 18.0 & Surficial \\
\hline 48 & 280634082453500 & Innisbrook ditch at bridge & - & - & Surface water \\
\hline 49 & 280635082452703 & Innisbrook NRSD well 3527.3 & 9.0 & 8.0 & Surficial \\
\hline \multirow[t]{2}{*}{50} & 280636082460601 & USGS NRSD well 3606 & 12.5 & 7.5 & Surficial \\
\hline & 280636082460602 & USGS FLRD well 3606 & 28.2 & 23.2 & Upper Floridan \\
\hline 51 & 280637082454404 & USGS NRSD well 15.4 & 11.0 & 10.0 & Surficial \\
\hline 52 & 280637082461201 & 3915 De Soto FLRD well & - & - & Upper Floridan \\
\hline 53 & 280639082452605 & Innisbrook NRSD well 3926.5 & 18.8 & 16.3 & Surficial \\
\hline 54 & 280639082452801 & Innisbrook FLRD well 5 & 105.0 & 60.0 & Upper Floridan \\
\hline \multirow[t]{2}{*}{55} & 280640082454101 & USGS FLRD well 2 & 27.0 & 24.0 & Upper Floridan \\
\hline & 280640082454102 & USGS NRSD well $2 \mathrm{~A}$ & 12.1 & 9.6 & Surficial \\
\hline 56 & 280640082455101 & $\begin{array}{l}\text { Plant diesel tank monitor } \\
\text { NRSD well }\end{array}$ & 17.8 & - & Surficial \\
\hline 57 & 28064108245290 I & $\begin{array}{l}\text { Innisbrook Lahinch Lodge } \\
\text { FLRD well }\end{array}$ & 120.0 & 40.0 & Upper Floridan \\
\hline 58 & 280641082454201 & USGS NRSD well 4142 & 9.6 & 4.6 & Surficial \\
\hline 59 & 280641082460101 & PinCo monitor well NP103 & 30.0 & 20.0 & Surficial \\
\hline \multirow[t]{2}{*}{60} & 280642082454601 & PinCo monitor well NP104 & 31.0 & 21.0 & Upper Floridan \\
\hline & 280642082454602 & USGS NRSD well 104A & 7.7 & 3.2 & Surficial \\
\hline 61 & 280642082455700 & Effluent pond at PinCo north plant & - & - & Surface water \\
\hline 62 & 280642082460201 & USGS NRSD well 4202 & 20.1 & 15.1 & Surficial \\
\hline 63 & 280645082455601 & PinCo monitor well NP102 & 34.0 & 14.0 & Surficial \\
\hline 64 & 280647082461401 & 811 Harry FLRD well & - & - & Upper Floridan \\
\hline \multirow[t]{2}{*}{65} & 280652082455401 & PinCo monitor well NP101 & 36.3 & 25.0 & Upper Floridan \\
\hline & 280652082455402 & USGS NRSD well $101 \mathrm{~A}$ & 9.5 & 7.0 & Surficial \\
\hline
\end{tabular}

${ }^{1}$ Locations of data-collection sites are shown in figure 2. 


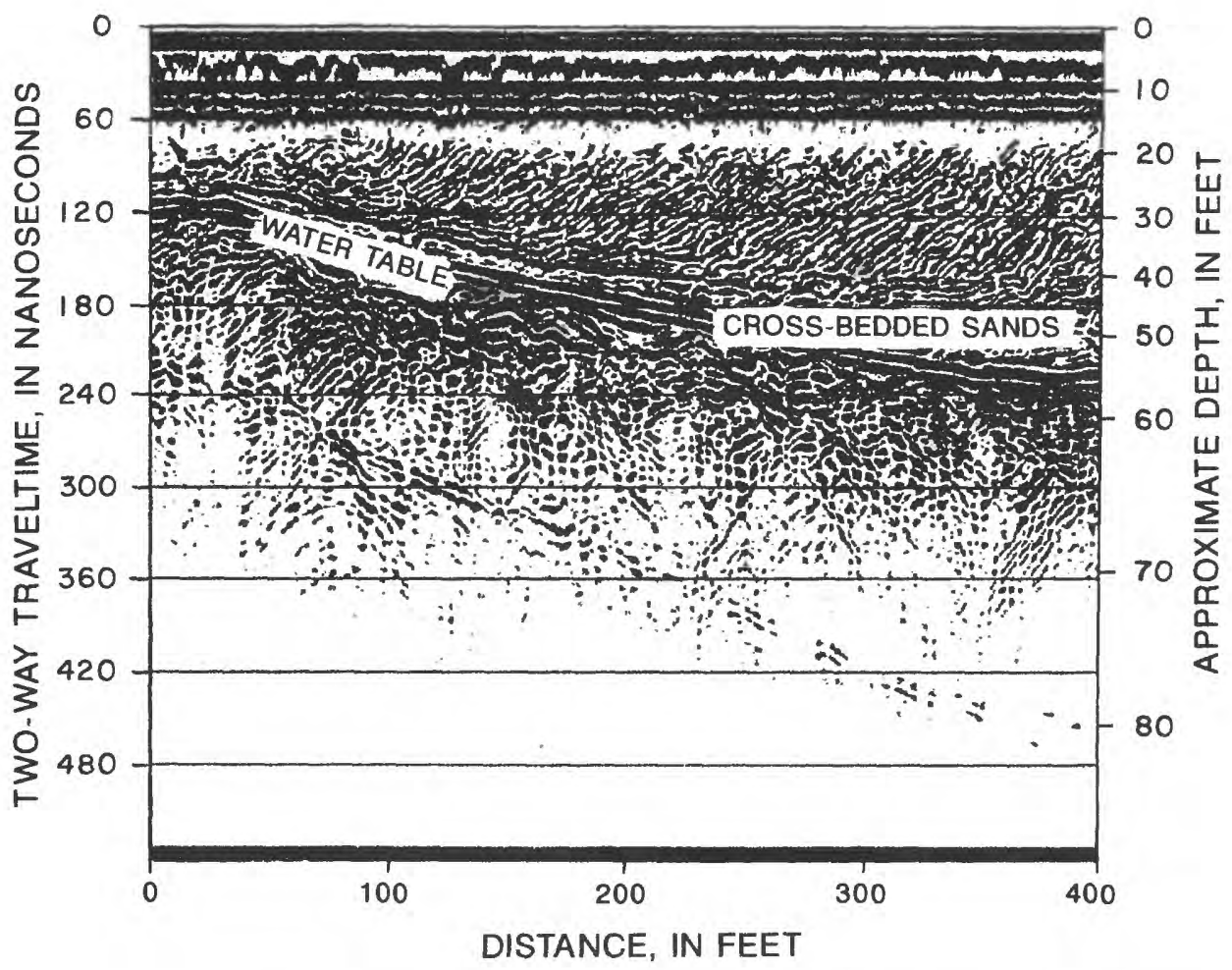

Figure 3. Ground-penetrating radar record showing cross-bedded surficial deposits at the study site.

\section{DESCRIPTION OF THE STUDY AREA}

The study area is south of Tarpon Springs in the northwestern part of Pinellas County and encompasses about $1 \mathrm{mi}^{2}$ (fig. 1). The area includes the North Pinellas County wastewater-treatment plant and disposal site (approximately 118 acres); an area of private single-family dwellings and recent commercial development to the west; part of a golf course at a resort to the north, east, and southeast; and an orange grove, pasture, and residential area to the south. The grove includes a $300-\mathrm{ft}$-wide strip of land between the sprayfield and the resort. The study area is bounded by the Gulf of Mexico to the west, a resort area to the north and east, and Bee Pond Road to the south (fig. 1).

\section{Topography and Drainage}

The study area lies within the Gulf Coastal Lowlands physiographic unit described by White $(1970$, p. 142$)$. The topography is dominated by rolling sand ridges, probably formed as sandbars or barrier islands that existed during ancient, higher sea levels. Subsequent sand dune activity during lower sea levels has altered these sandbars or islands to near present day altitudes (Heath and Smith, 1954, p. 9). Cross-bedded sand patterns, which are indicative of windblown deposition, are evident on some GPR profiles (fig. 3) that were collected during the study period. Mineralogic analyses of the surficial sands also indicate a beach and dune depositional environment (McCarten and others, 1992). Radar data and periodic sinkhole occurrences indicate the variable surface topography (fig. 4) also may be due, in part, to dissolution and subsidence activity.

Generally, land-surface altitude ranges from sea level at the coast to about $65 \mathrm{ft}$ above sea level on the golf course in the southeastern part of the study area. A small pond exists at the boundary of the disposal site near U.S. Highway A19 and appears to be a sinkhole remnant. Prior to late 1988, a shallow depression existed in the central part of the sprayfield (fig. 1). The depression was filled and graded to a higher elevation to eliminate ponding of water when onsite spray irrigation occurred. Within the treatment plant and at onsite disposal areas, land-surface altitudes rise from about $4 \mathrm{ft}$ above sea level in the depression and in a swampy area at the northern boundary to about $30 \mathrm{ft}$ above sea level on a sand ridge at the southern boundary. The ridge continues southwesterly through the golf course and reaches an altitude of about $60 \mathrm{ft}$ above sea level in the southeastern part of the 


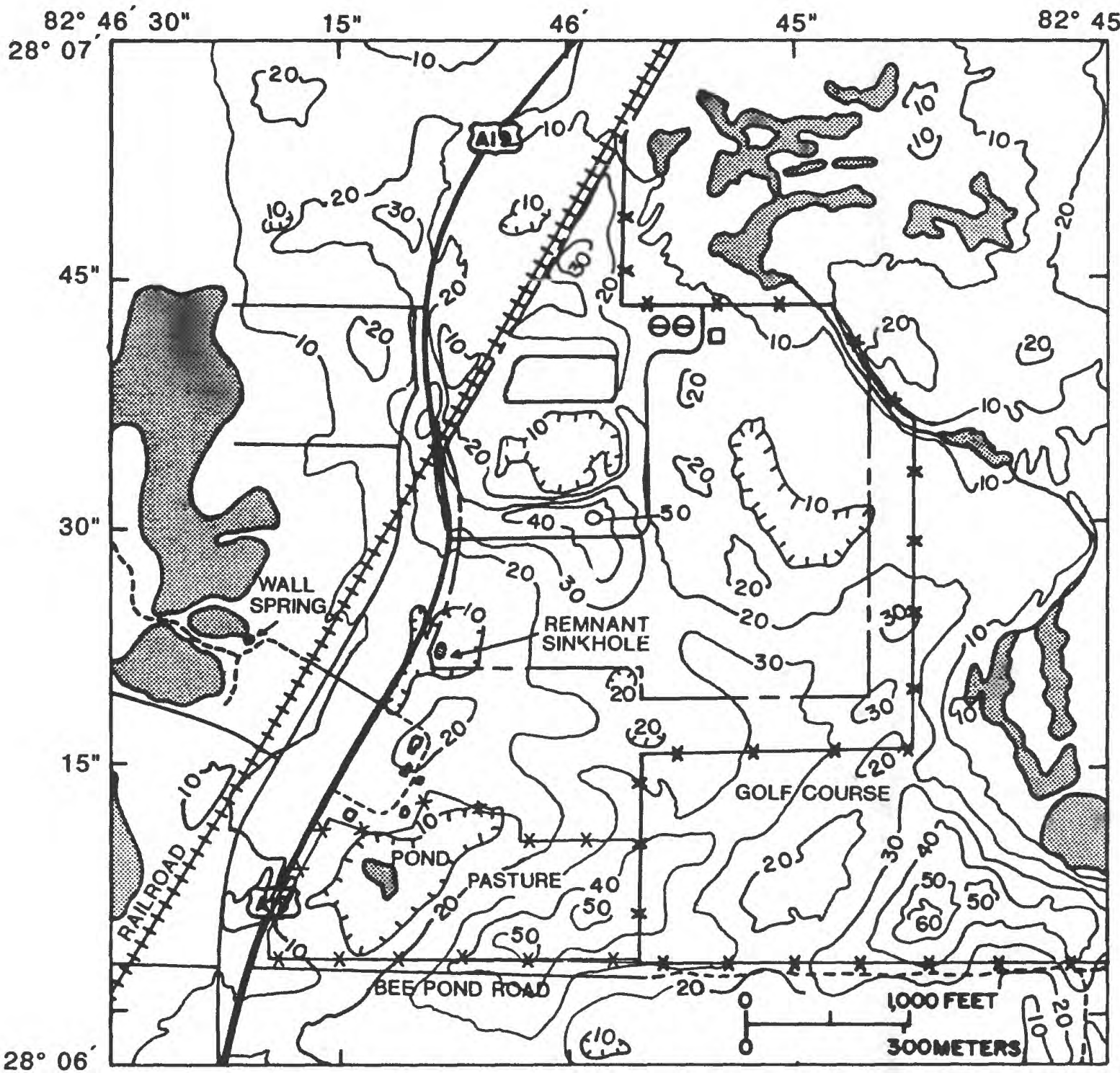

EXPLANATION

AREA OF STANDING WATER

TREATMENT-PLANT AND DISPOSAL-SITE BOUNDARY

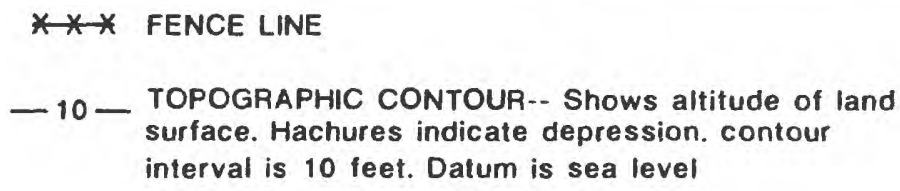
- TOPOGRAPHIC CONTOUR-- Shows altitude of land
surface. Hachures indicate depression. contour interval is 10 feet. Datum is sea level

Figure 4. Topography of the study area prior to 1988. 
pasture; it then slopes steeply to the west, forming a large shallow depression. A manmade pond occupies the center of this depression (fig. 4).

Because the study area is blanketed by well-drained, fine sand, drainage is internal with no stream channel development. Recharge percolates downward to the water table and then moves horizontally to areas of discharge. At the study site, discharge occurs through discontinuities in the semiconfining bed to the Upper Floridan aquifer and as ground-water discharge to a manmade lake and ditch system on the resort property. This system eventually drains to the Gulf of Mexico. The depression in the central part of the disposal site formed a small lake during onsite spray irrigation activities when ground-water levels rose above land surface. Because there is no surface outlet, water remained ponded in the depression until the level of disposal activity decreased, allowing water levels to recede below land surface. This usually occurred during the dry season when effluent was diverted to the golf courses at the resort. Since the depression was filled in late 1988, ponding has not occurred. The pond in the pasture and the sinkhole remnant contain water perennially.

\section{Hydrogeology}

Northwestern Pinellas County is underlain by thick sequences of carbonate rock that were deposited in a marine environment during the Tertiary Period. Clastic deposits of sand, silt, and clay of Miocene age and marine terrace sands of Pleistocene age overlie the carbonate rock (Heath and Smith, 1954). At the disposal site, much of the clastic Miocene deposits have been stripped away by erosion that occurred between alternating periods of higher and lower sea-level stands. Only a thin calcareous residuum separates the surficial sand from the underlying limestone. Resulting internal drainage and solution activity have formed a highly irregular limestone surface with vertical solution pipes, cavities, and other features typical of karst environments. The geologic sections in figure 5 are based on drilling and GPR data and show the surface topography, the thickness of the surficial sands and residuum, and the irregular nature of the underlying limestone in the study area.

Deposits at the study site form three major hydrogeologic units: the surficial aquifer, the intermediate confining unit, and the Floridan aquifer system. The hydrogeologic units, corresponding stratigraphic units, and general lithology are presented in table 2.

The surficial aquifer is an unconfined sand aquifer. Drilling and GPR data show the surficial deposits range in thickness from 5 to $50 \mathrm{ft}$; however, the thickness of the surficial aquifer (saturated deposits above the residuum) ranges from less than $1 \mathrm{ft}$ to about $15 \mathrm{ft}$. Because of the topography at the study site, depth to the water table is variable, ranging from a few inches in depressions to more than $50 \mathrm{ft}$ below land surface on higher ridges. Drilling and radar data also indicate that, in an area around Wall Springs, the residuum pinches out and the surficial aquifer is absent.

Laboratory estimates of hydraulic conductivity for nine samples collected from the surficial aquifer at the disposal site ranged from 1.0 to $5.9 \mathrm{ft} / \mathrm{d}$ and averaged $3 \mathrm{ft} / \mathrm{d}$. Based on the estimated hydraulic conductivity and aquifer thickness, the transmissivity of the surficial aquifer is estimated to range from 3 to $45 \mathrm{ft}^{2} / \mathrm{d}$.

Prior to disposal operations, recharge to the surficial aquifer was primarily from local rainfall. In the Tarpon Springs area, average annual rainfall is about $52 \mathrm{in} / \mathrm{yr}$ (National Oceanic and Atmospheric Administration, 1988). Of this, about $35 \mathrm{in} / \mathrm{yr}$ is returned to the atmosphere as evapotranspiration (Dohrenwend, 1977), leaving about 17 in/yr to recharge the surficial aquifer, assuming there is no runoff. This is approximately equivalent to $56 \mathrm{Mgal}$ annually over the 118-acre treatment plant and disposal site.

In the study area, discharge from the surficial aquifer occurs as lateral ground-water outflow to surface-water bodies or as downward leakage to the Upper Floridan aquifer. The surficial aquifer is not used as a source of water in the study area.

Generally, the surficial aquifer in Pinellas County is underlain by a confining unit that restricts the vertical movement of water to the Upper Floridan aquifer. It has been designated the intermediate confining unit by the Southeastern Geological Society (1986, p. 8) and also is referred to as the upper confining unit of the Floridan aquifer system (Miller, 1986). The intermediate confining unit generally consists of deposits of olive-green clay, silt, and sandy, calcareous clay of the Miocene Hawthorn Formation. At the disposal site, however, only a few scattered remnants of the Hawthorn deposits were encountered in depressions or relict sinkholes in the underlying limestone. Throughout most of the study area, only a thin, discontinuous, white, calcareous, sandy, residuum layer separating the limestone from the overlying surficial sands was encountered. Samples of the residuum contained 60 to 70 percent sand and 20 to 30 percent clay-sized particles. Mineralogic determination using X-ray defraction analysis, conducted by the U.S. Geological Survey, indicates that the residuum probably is derived from the weathering of the Tampa Limestone rather than from the Hawthorn deposits (McCarten and others, 1992). The residuum forms the intermediate confining unit at the study site.

Drilling and radar data collected during this study indicate that, where present, the residuum is variable and ranges in thickness from less than $1 \mathrm{ft}$ to about $15 \mathrm{ft}$. West of the disposal site near Wall Springs, the residuum is not present. Less than $10 \mathrm{ft}$ of surficial sand directly overlies the hard limestone in this area. Throughout the study area, the surface of the residuum layer is usually encountered between $5 \mathrm{ft}$ above and $15 \mathrm{ft}$ below sea level; however, it has been located at depths up to $50 \mathrm{ft}$ below sea level in paleokarst features encountered in test drilling. The surface of the residuum is irregular and reflects the irregular surface of the underlying limestone (fig. 5). 


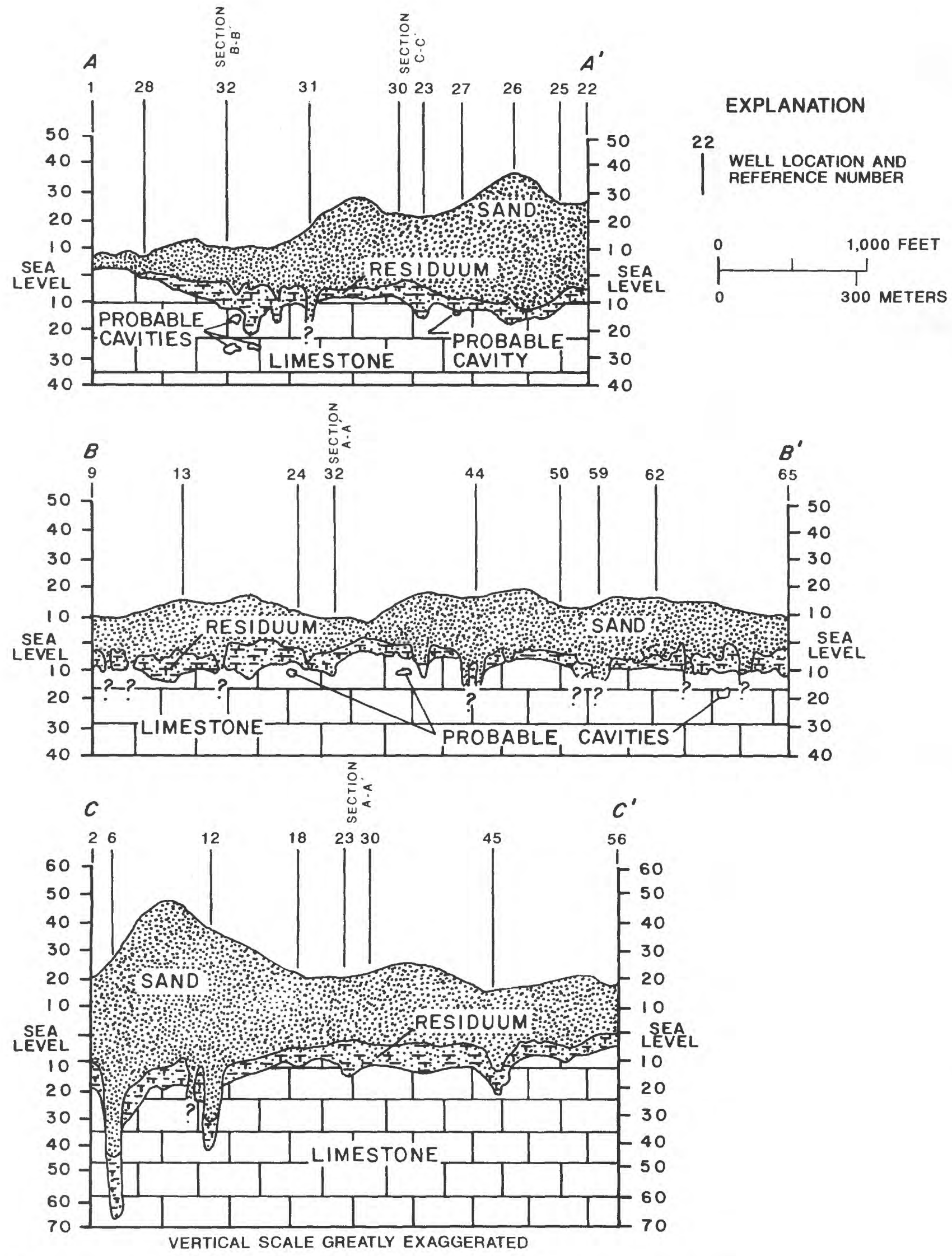

Figure 5. Geologic sections $A-A^{\prime}, B-B^{\prime}$, and $C-C$. (Traces of sections are shown in fig. 2.) 
Table 2. Hydrogeologic framework

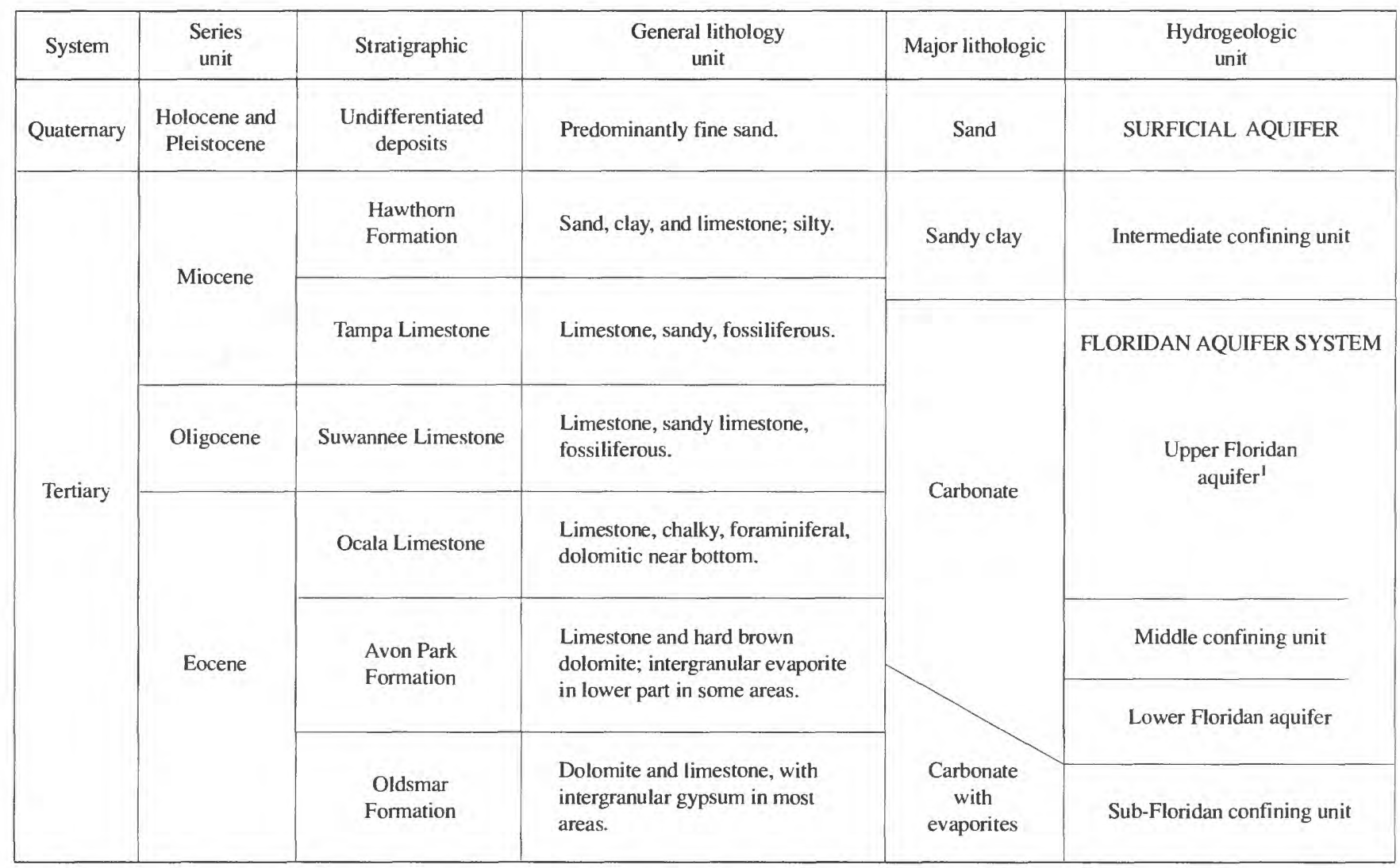

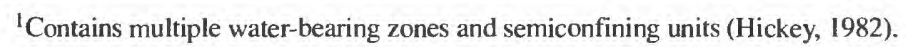

Hydraulic conductivity estimates for residuum samples collected at the study site ranged from $4 \times 10^{-2}$ to $1.8 \times 10^{-1} \mathrm{ft} / \mathrm{d}$ and averaged about $8 \times 10^{-2} \mathrm{ft} / \mathrm{d}$. An average hydraulic conductivity value of $2 \times 10^{-3} \mathrm{ft} / \mathrm{d}$ was determined during a previous study at the adjacent resort (Brown, 1981, p. 13). The residuum layer generally thickens and contains more clay east of the study area.

Drillers' logs, GPR surveys, and the occurrence of sinkholes indicate that the residuum is breached in many places, allowing good hydraulic connection to the underlying limestone. At best, the residuum forms a leaky, semiconfining unit that separates the surficial aquifer from the Upper Floridan aquifer.

In the study area, the Miocene Tampa Limestone is the uppermost carbonate rock and it forms the top of the Upper Floridan aquifer. Because of the nature of the intermediate confining unit, the Upper Floridan aquifer is semiconfined, with the exception of the area near Wall Springs where it is unconfined. The Upper Floridan aquifer at the disposal site is approximately $1,000 \mathrm{ft}$ thick (Wolansky and Garbade, 1980; Miller, 1986). Because of the proximity of the study area to the coast, however, freshwater is present only in approximately the upper $150 \mathrm{ft}$ of the Upper Floridan aquifer.
In the study area, the top of the Upper Floridan aquifer averages between 10 and $15 \mathrm{ft}$ below sea level, except near the coast where its surface is at or slightly above sea level. At some drilling sites, the limestone was first encountered at depths greater than $80 \mathrm{ft}$ below sea level (fig. 5), indicating the presence of sediment-filled paleosinkholes. Drilling activities and GPR surveys show solution cavities, limestone pinnacles, and subsidence features typical of karst environments throughout the study area. The GPR profile shown in figure 6 illustrates some of these features. Development of seven sinkholes at the disposal site during 1988 and 1989 further indicates the highly karstified nature of the Tampa Limestone. The occurrence of subsurface cavities suggests that a highly developed secondary porosity exists within the Tampa Limestone at the study site.

From aquifer tests conducted in northwestern Hillsborough and northeastern Pinellas Counties, transmissivity of the Upper Floridan aquifer was estimated to range from 33,000 to $58,800 \mathrm{ft}^{2} / \mathrm{d}$ (Wolansky and Corral, 1985, p. 31). Assuming an average aquifer thickness of $1,000 \mathrm{ft}$, the equivalent horizontal hydraulic conductivity values would be 33 to $59 \mathrm{ft} / \mathrm{d}$. Because highly developed secondary porosity in the aquifer in the trough area west of the disposal site, hydraulic conductivity may be higher, particularly in the vicinity of Wall Springs (fig. 1). 
Recharge to the Upper Floridan aquifer at the study site is by downward leakage from the surficial aquifer. Although some recharge occurs through the semipermeable residuum layer, most recharge probably occurs at breaks in the residuum where leakage rates could be high.

Discharge from the Upper Floridan aquifer in the study area occurs as pumpage from area wells, as flow from Wall Springs, and through submarine springs and seeps along the coastal margin. Less than 25 single-family residences to the south and west of the disposal site use private wells for their water supply. Prior to 1990, the Upper Floridan aquifer was the sole source of supply for these residences, but potable water from the county public-supply system is now available.

\section{Predisposal Ground-Water Flow System}

The water table of the surficial aquifer prior to effluent disposal is shown in figure 7 (Brown, 1981, p. 21). A large area of low water levels (ground-water trough) extends from the area near Wall Springs in the western part of the study area, through the central part of the area, to the resort.
A smaller area of lower water levels forms a trough that underlies a drainage ditch in the northeastern part of the study area. The drainage ditch is part of the manmade lake system at the resort. The smaller trough is a result of groundwater discharge from the surficial aquifer to the ditch. There are no surface drainage features in the area underlain by the large trough, which indicates discharge is internal to the Upper Floridan aquifer. GPR surveys and drilling activities for the current study indicate that a thin, discontinuous residuum layer exists between the aquifers in this trough area.

The direction of ground-water flow in the surficial aquifer before disposal operations began was from areas of higher water levels in the northern, eastern, and southern parts of the study area toward the trough and then westward toward the coast. Water levels during September 1974 ranged from less than $3 \mathrm{ft}$ above sea level in the western part of the trough to about $7 \mathrm{ft}$ above sea level in the southern part of the study area.

Insufficient data are available to map the potentiometric surface of the Upper Floridan aquifer in the study area for September 1974. On a regional basis, flow in the aquifer is generally from east to west across the area.

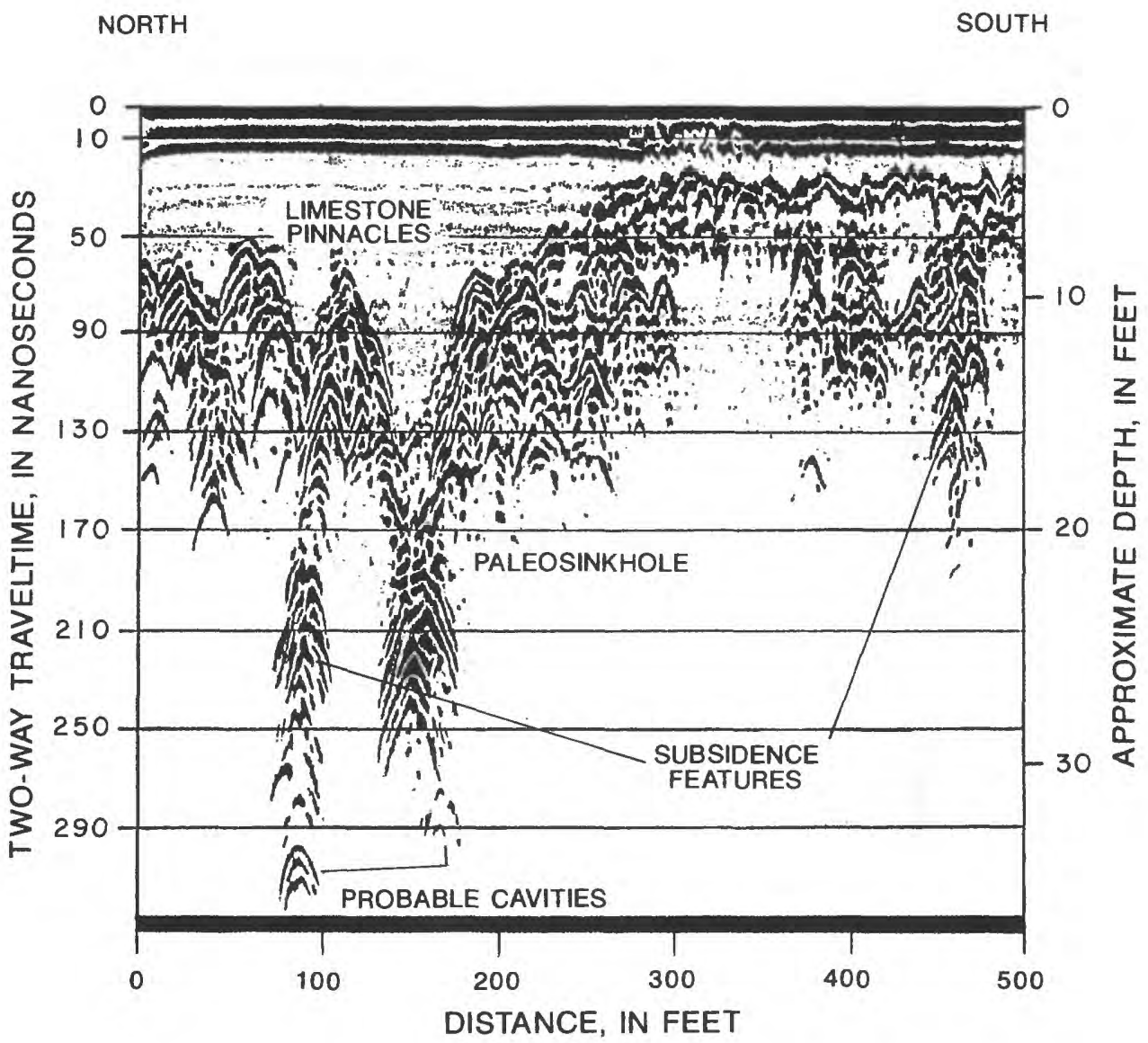

Figure 6. Ground-penetrating radar record showing the irregular surface of the underlying sediments at the study site. 

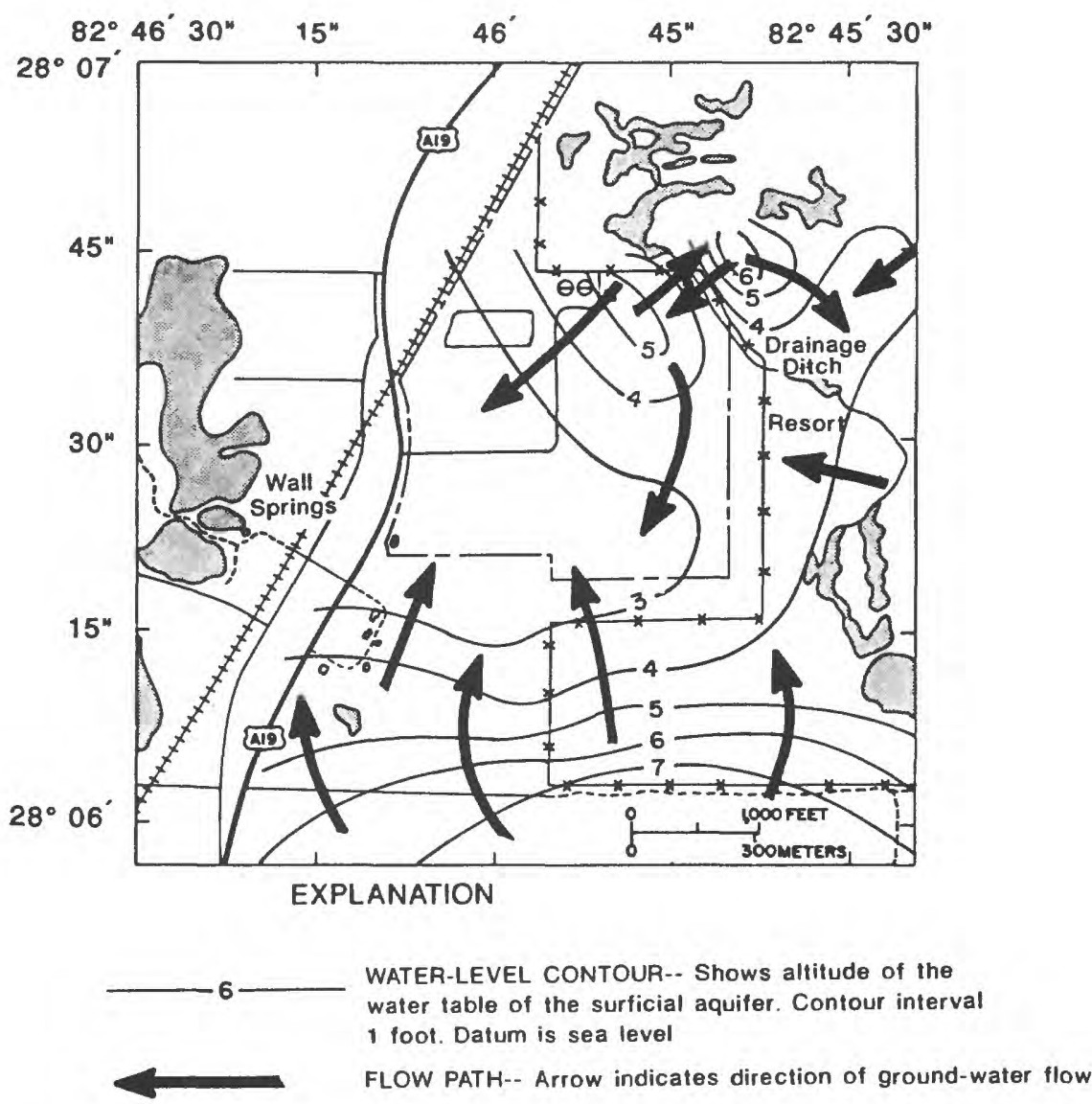

Figure 7. Configuration of the water table of the surficial aquifer prior to disposal operations, September 1974. (Modified from Brown, 1981.)

\section{Background Water Quality}

Analyses of samples collected in 1974 (prior to disposal) from well sites 38 and 51 were used to determine background water quality in the surficial aquifer (table 3 ). The 1974 analyses represent native ground water in this aquifer. Both wells are in areas that are presently being used for effluent disposal. Prior to disposal operations, water in the surficial aquifer was low in specific conductance, was acidic, and contained low concentrations of inorganic constituents and nutrients. Specific conductance of samples from wells in the surficial aquifer at sites 38 and 51 were 62 and $108 \mu \mathrm{S} / \mathrm{cm}$, respectively; $\mathrm{pH}$ was 5.1 and 6.3 ; and total nitrogen concentrations were 0.28 and $0.59 \mathrm{mg} / \mathrm{L}$, with the dominant species being organic nitrogen. Total phosphorus concentrations were low, averaging $0.03 \mathrm{mg} / \mathrm{L}$. Most trace metals were either not detected or were below levels expected for natural waters (Hem, 1985). Concentrations of major ions also were within expected ranges.
Water quality in the upper part of the Upper Floridan aquifer prior to effluent disposal at the study area was determined from an analysis of a sample collected in 1972 from a $105-\mathrm{ft}-$ deep well in the northeastern part of the study area (site 54). Specific conductance and $\mathrm{pH}$ of this sample were $265 \mu \mathrm{S} / \mathrm{cm}$ and 8.2, respectively. Chloride concentration was $20 \mathrm{mg} / \mathrm{L}$ and the calcium concentration was $40 \mathrm{mg} / \mathrm{L}$. Concentrations of nutrients and other major ions were within ranges deemed suitable for drinking water (Florida Department of Environmental Regulation, 1989).

\section{DISPOSAL OPERATIONS}

Prior to December 1989, the North Plant consisted of two $1.5-\mathrm{Mgal} / \mathrm{d}$ package wastewater-treatment units that were operated as a single 3-Mgal/d secondary treatment facility using an activated sludge process. Effluent from this facility was chlorinated and discharged to a plastic-lined 
Table 3. Summary of selected background water-quality data IConcentrations are in milligrams per liter, except where noted. $\mu \mathrm{S} / \mathrm{cm}$, microsiemens per centimeter; $\mu \mathrm{g} / \mathrm{L}$, micrograms per liter; -, no data; $<$, less than]

\begin{tabular}{lcccc}
\hline & \multicolumn{2}{c}{ Surficial aquifer } & $\begin{array}{c}\text { Upper Floridan } \\
\text { aquifer }\end{array}$ \\
\cline { 2 - 3 } \multicolumn{1}{c}{ Constituent or property } & $\begin{array}{c}\text { Well } \\
\text { site } 38\end{array}$ & $\begin{array}{c}\text { Well } \\
\text { site } 51\end{array}$ & $\begin{array}{c}\text { Well } \\
\text { site } 54\end{array}$ \\
& $5-23-74$ & $5-23-74$ & $6-06-72$ \\
\hline Specific conductance $(\mu \mathrm{S} / \mathrm{cm})$ & 62 & 108 & 265 \\
pH $($ units $)$ & 5.1 & 6.3 & 8.2 \\
Alkalinity & - & - & 96 \\
Dissolved solids & 32 & - & 162 \\
Organic nitrogen as N & .13 & .37 & - \\
Ammonia nitrogen as N & .05 & .14 & - \\
Nitrite plus nitrate nitrogen as N & .10 & .08 & .08 \\
Phosphorus, total as P & .02 & .04 & .05 \\
Chloride, dissolved & 3.3 & 4.8 & 20 \\
Sulfate, dissolved & - & - & 40 \\
Sodium, dissolved & 1.9 & 2.4 & 6.9 \\
Potassium, dissolved & 1.3 & .5 & .4 \\
Calcium, dissolved & 6 & 21 & 40 \\
Magnesium, dissolved & 1.3 & 1.4 & 3 \\
Arsenic, total $(\mu \mathrm{g} / \mathrm{L})$ & $<1.0$ & 2 & - \\
Copper, total $(\mu \mathrm{g} / \mathrm{L})$ & - & - & - \\
Iron, total $(\mu \mathrm{g} / \mathrm{L})$ & -1.0 & 3,200 & - \\
Lead, total $(\mu \mathrm{g} / \mathrm{L})$ & - & - & - \\
Mercury, total $(\mu \mathrm{g} / \mathrm{L})$ & .6 & $<.5$ & - \\
Strontium, dissolved $(\mu \mathrm{g} / \mathrm{L})$ & - & - & 160 \\
Zinc, total $(\mu \mathrm{g} / \mathrm{L})$ & - & - & - \\
\hline & & & & - \\
\hline
\end{tabular}

holding pond (fig. 1) until it was pumped to the sprayfield for disposal. Effluent has been disposed of onsite, except during dry periods when part or all of the effluent has been used to irrigate golf courses at the adjacent resort. Sludge has been stored onsite in unlined earthen basins (fig. 1) and allowed to dewater by evaporation and percolation to the underlying surficial sands. Prior to 1988 , dried sludge was removed from the drying beds and spread at various locations within the disposal site boundary. Onsite sludge disposal at the North Plant was discontinued in 1988.

Rapid development in the area and an increasing volume of wastewater being processed by the North Plant prompted construction of expanded wastewater-treatment facilities in 1988. The new treatment plant has a design capacity of $9 \mathrm{Mgal} / \mathrm{d}$ and has been upgraded from a secondary to an advanced treatment system with nutrient removal. Expansion included the addition of a larger effluent holding pond south of the original pond and the conversion of two previously unused areas of county property to sprayfields, bringing the total acreage available for effluent disposal to about 87 acres. The first area is south of the new effluent holding pond. Irrigation started at this sprayfield in mid-1988. The second area is the hilly area north of the original effluent holding pond. Irrigation at this sprayfield started in mid-1989. The new sprayfields include areas formerly used for sludge drying basins. Irrigation in these areas is limited only to volumes sufficient to maintain a grass cover (Dave Slonena, Pinellas County Sewer System, written commun., 1991), The new plant went into service in December 1989. The new treatment plant and expanded disposal site is shown in figure 8 .

As a result of disposal operations, $3 \mathrm{Mgal} / \mathrm{d}$ or 1.1 $\mathrm{Ggal} / \mathrm{yr}$ of effluent is available to infiltrate the surficial aquifer. During 1988, an estimated $410 \mathrm{Mgal}$ were diverted to the golf courses at the adjacent resort, leaving about $685 \mathrm{Mgal}$ of effluent disposed of onsite. When disposed of over the 87 acres of sprayfields, the volume would be equivalent to about $290 \mathrm{in} / \mathrm{yr}$. In addition, rainfall in the study area for 1988 was 56.4 in. Because of near saturation conditions that occur during spraying, evapotranspiration rates probably approach calculated potential rates. The potential evapotranspiration rate for northern Pinellas County is about 45 in/yr (Dohrenwend, 1977). Therefore, annual infiltration to the surficial aquifer at the disposal site was probably greater than 300 in. during 1988. In 1990, a reuse water system that delivers effluent to numerous offsite locations began operation. This reclamation system reduces the amount of effluent that must be disposed of at the study site.

Between 1987 and 1989, three samples were collected from the effluent holding pond and analyzed to characterize the chemical quality of the effluent. A summary of selected water-quality constituents in the effluent is presented in table 4. Although the samples were collected at different times, concentrations of the various chemical constituents are similar. The mean specific conductance was $1,113 \mu \mathrm{S} / \mathrm{cm}$ and the mean dissolved-solids concentration was $621 \mathrm{mg} / \mathrm{L}$. The $\mathrm{pH}$ was slightly alkaline, ranging from 7.5 to 7.7 . Alkalinity ranged from 203 to $321 \mathrm{mg} / \mathrm{L}$. Total nitrogen concentration ranged from 12.30 to $18.25 \mathrm{mg} / \mathrm{L}$, with a mean concentration of $14.90 \mathrm{mg} / \mathrm{L}$. Ammonia nitrogen and organic nitrogen were the dominant species, accounting for more than 90 percent of the total nitrogen concentration in two samples. The third sample collected on June 24,1987 , contained only $6.10 \mathrm{mg} / \mathrm{L}$ of ammonia nitrogen and $0.97 \mathrm{mg} / \mathrm{L}$ of organic nitrogen; however, it also contained $6.48 \mathrm{mg} / \mathrm{L}$ of nitrate nitrogen compared to 1.05 and $0.25 \mathrm{mg} / \mathrm{L}$ for the other two samples. Ammonia and organic nitrogen accounted for only 50 percent of the total nitrogen in this sample. The reason for lower ammonia and organic nitrogen and high nitrate concentrations in this sample is unknown. The mean total phosphorus concentration in the effluent samples was $5.1 \mathrm{mg} / \mathrm{L}$; the dominant species was orthophosphorus. Major ion concentrations in the effluent were higher than those in native ground water, with the mean sodium and chloride concentrations being 130 and $170 \mathrm{mg} / \mathrm{L}$, respectively. Trace metal concentrations in the effluent were similar to concentrations in native ground water. MBAS, an indicator of linear alkylbenzene sulfonates (and other similar compounds), is used to indicate the presence of detergents. Concentrations of MBAS in effluent samples averaged about $0.32 \mathrm{mg} / \mathrm{L}$, confirming the presence of detergents in the effluent. 


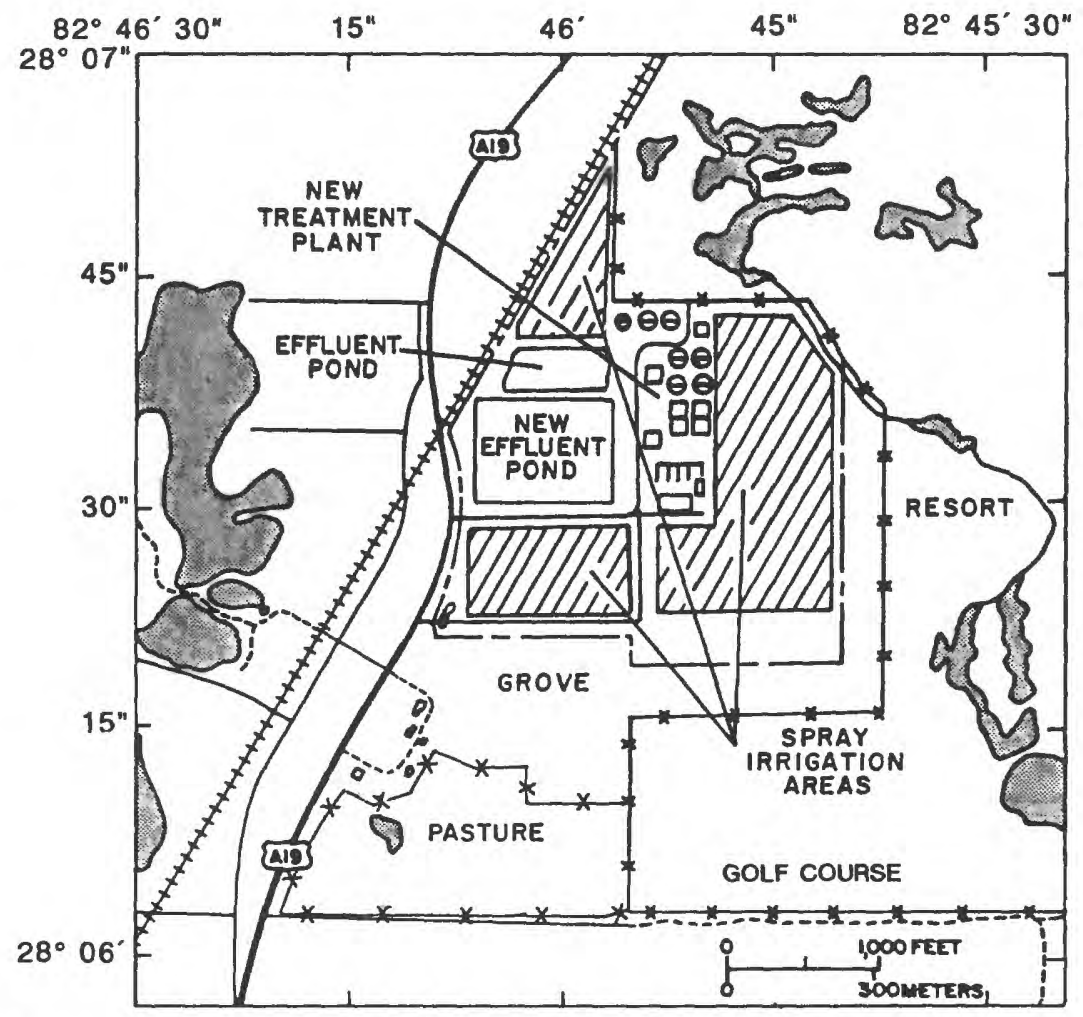

Figure 8. Location of treatment plant and disposal site after 1988.

\section{EFFECTS OF EFFLUENT SPRAY IRRIGATION AND SLUDGE DISPOSAL.}

Disposal of effluent by spray irrigation has affected the water table of the surficial aquifer and the potentiometric surface of the Upper Floridan aquifer in the study area. Water quality in both aquifers also has been affected by disposal operations.

\section{Ground-Water Levels and Flow System}

Except for the coastal area near Wall Springs, there are two separate but related ground-water flow systems in the study area. Although differences in local flow patterns exist in the surficial aquifer and the Upper Floridan aquifer, hydrographs of clustered wells (fig. 9) show small head differences and parallelism in water-level fluctuation, which indicates that the interconnection between the two aquifers is good throughout the study area.

Maps of the water table of the surficial aquifer for May and September 1988 (fig. 10) show some similarities to the September 1974 predisposal water-table map (fig. 7). The same ground-water troughs are present in the surficial aquifer, however, the large trough through the center of the study area was not as extensive in 1988 as it was in 1974.

Effluent disposal has resulted in a large ground-water mound underlying the areas that are being spray irrigated (fig. 10). The mound trends in a slight northwest-southeast direction, extending from the northern boundary of the disposal site to and including part of a golf course lying south of the sprayfield. The mound spreads east and west under most of the golf course. During the study period, the larger ground-water trough southwest of the ground-water mound formed a wedge into the mound between the sprayfield and the golf course. The trough under the drainage ditch forms the northeast boundary of the mound.

Water-level fluctuations in surficial aquifer wells in the area of the mound were influenced more by the volume of effluent being sprayed than by the seasonal precipitation. During May 1988, water levels were less than $2 \mathrm{ft}$ above sea level in both trough areas and about $6 \mathrm{ft}$ above sea level in the mound area (fig. 10). September water levels were about $6 \mathrm{ft}$ above sea level in the trough southwest of the disposal site and less than $4 \mathrm{ft}$ above sea level in the trough underlying the drainage ditch. Water levels in the mound were greater than $12 \mathrm{ft}$ above sea level. 
Table 4. Summary of selected water-quality data for samples from the effluent holding pond

[Concentrations are in milligrams per liter, except where noted. $\mu \mathrm{S} / \mathrm{cm}$, microsiemens per centimeter; $\mu \mathrm{g} / \mathrm{L}$, micrograms per liter; -, no data; $<$, less than]

\begin{tabular}{|c|c|c|c|}
\hline Constituent or property & $\begin{array}{c}\text { June } 24 \\
1987\end{array}$ & $\begin{array}{c}\text { August 10, } \\
1988\end{array}$ & $\begin{array}{c}\text { March 9, } \\
1989\end{array}$ \\
\hline Specific conductance $(\mu \mathrm{S} / \mathrm{cm})$ & 1,080 & 1,120 & 1,140 \\
\hline $\mathrm{pH}$ (units) & 7.5 & 7.7 & 7.5 \\
\hline Dissolved solids & 624 & 606 & 634 \\
\hline Alkalinity & 203 & 212 & 321 \\
\hline Organic nitrogen as $\mathrm{N}$ & .97 & 2.30 & 1.00 \\
\hline Ammonia nitrogen as $\mathrm{N}$ & 6.10 & 8.70 & 17.00 \\
\hline Nitrite nitrogen as $\mathrm{N}$ & .62 & .25 & .18 \\
\hline Nitrate nitrogen as $\mathrm{N}$ & 6.48 & 1.05 & .07 \\
\hline Total nitrogen as $\mathrm{N}$ & 14.17 & 12.30 & 18.25 \\
\hline Phosphorus, ortho as $\mathrm{P}$ & 5.2 & 3.8 & 4.6 \\
\hline Phosphorus, total as $\mathrm{P}$ & 6.2 & 4.3 & 4.8 \\
\hline Chloride, dissolved & 170 & 180 & 160 \\
\hline Sulfate, dissolved & 29 & 34 & 34 \\
\hline Sodium, dissolved & 140 & 130 & 120 \\
\hline Potassium, dissolved & 12 & 21 & 32 \\
\hline Calcium, dissolved & 65 & 68 & 72 \\
\hline Magnesium, dissolved & 6.0 & 5.6 & 5.7 \\
\hline Silica, dissolved & 17 & 18 & 17 \\
\hline Methylene blue active substance & .20 & .26 & .49 \\
\hline Aluminum, total $(\mu \mathrm{g} / \mathrm{L})$ & 50 & - & - \\
\hline Arsenic, total $(\mu \mathrm{g} / \mathrm{L})$ & 1 & - & - \\
\hline Barium, total $(\mu \mathrm{g} / \mathrm{L})$ & $<100$ & - & - \\
\hline Boron, total $(\mu \mathrm{g} / \mathrm{L})$ & 240 & - & - \\
\hline Cadmium, total $(\mu \mathrm{g} / \mathrm{L})$ & 2 & - & - \\
\hline Chromium, total $(\mu \mathrm{g} / \mathrm{L})$ & $<1.0$ & - & - \\
\hline Copper, total $(\mu \mathrm{g} / \mathrm{L})$ & 30 & - & - \\
\hline Iron, total $(\mu \mathrm{g} / \mathrm{L})$ & 90 & - & - \\
\hline Lead, total $(\mu \mathrm{g} / \mathrm{L})$ & 9 & - & - \\
\hline Mercury, total $(\mu \mathrm{g} / \mathrm{L})$ & $<.10$ & - & - \\
\hline Nickel, total $(\mu \mathrm{g} / \mathrm{L})$ & 4 & - & - \\
\hline Strontium, dissolved $(\mu \mathrm{g} / \mathrm{L})$ & 200 & 200 & 250 \\
\hline Zinc, total $(\mu \mathrm{g} / \mathrm{L})$ & 30 & - & - \\
\hline
\end{tabular}

The direction of ground-water flow in the surficial aquifer at the disposal site is from the mound toward the troughs. On the part of the resort that lies south of the disposal site, sprayed effluent reaches the water table and causes, or at least amplifies, the southern extent of the ground-water mound. Flow direction in the surficial aquifer in this part of the study area is west and northwest under the pastureland toward the large central trough. Flow in the trough area is toward the west. The surficial aquifer also discharges to the underlying Upper Floridan aquifer in this area. Throughout the period of study, general flow patterns in the surficial aquifer remained consistent, showing little seasonal change even though water levels fluctuated by more than $6 \mathrm{ft}$ in some wells.

A trough in the potentiometric surface of the Upper Floridan aquifer underlies the same area as the large trough in the surficial aquifer. The general location of the trough also remained consistent throughout the study period even though seasonal water-level fluctuations varied by about $3 \mathrm{ft}$. Water levels in wells in the area of the trough ranged from less than $2 \mathrm{ft}$ above sea level in May 1988 to nearly $5 \mathrm{ft}$ above sea level in September 1988 (fig. 11). One possible explanation for the trough is that it represents an area of increased transmissivity resulting from the development of secondary porosity in the Tampa Limestone. Water could move more rapidly through the solution-enlarged openings toward discharge areas, thereby lowering the head in the aquifer in this area.

Mounding in the Upper Floridan aquifer under the disposal site indicates increased recharge from the surficial aquifer to the Upper Floridan aquifer during disposal periods. Effluent disposal activities at the site caused a large water-table mound in the surficial aquifer (fig. 10), and a similar mound was observed in the potentiometric surface of the underlying Upper Floridan aquifer. The mound was almost nonexistent in the Upper Floridan aquifer during dry periods when effluent was diverted to the resort golf courses and the water table in the surficial aquifer at the disposal site declined. Although mounding occurred in the surficial aquifer at the resort golf course (fig. 10), a similar mound did not occur in the underlying Upper Floridan aquifer (fig. 11). Hydraulic connection between the aquifers is inferred to be less direct in this area.

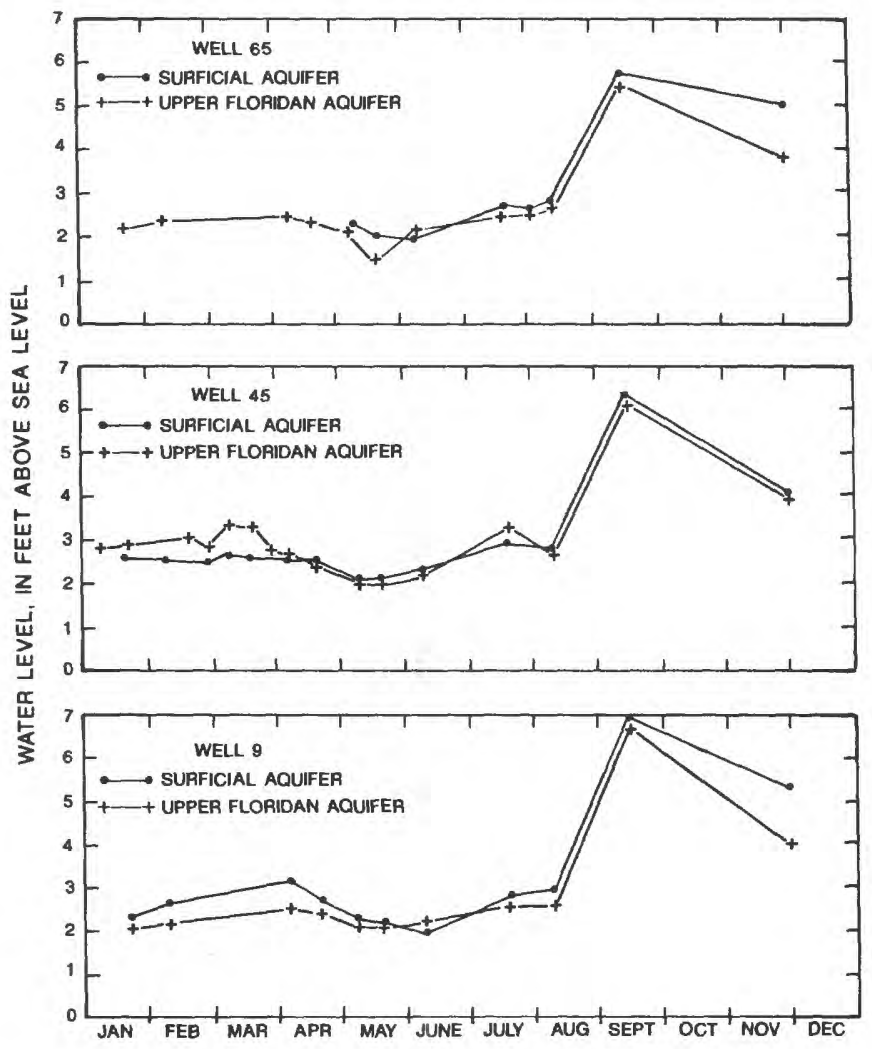

Figure 9. Water levels in the surficial and Upper Floridan aquifer wells in 1988 indicating small head difference and similar water-level fluctuations. (Well locations are shown in fig. 2.) 

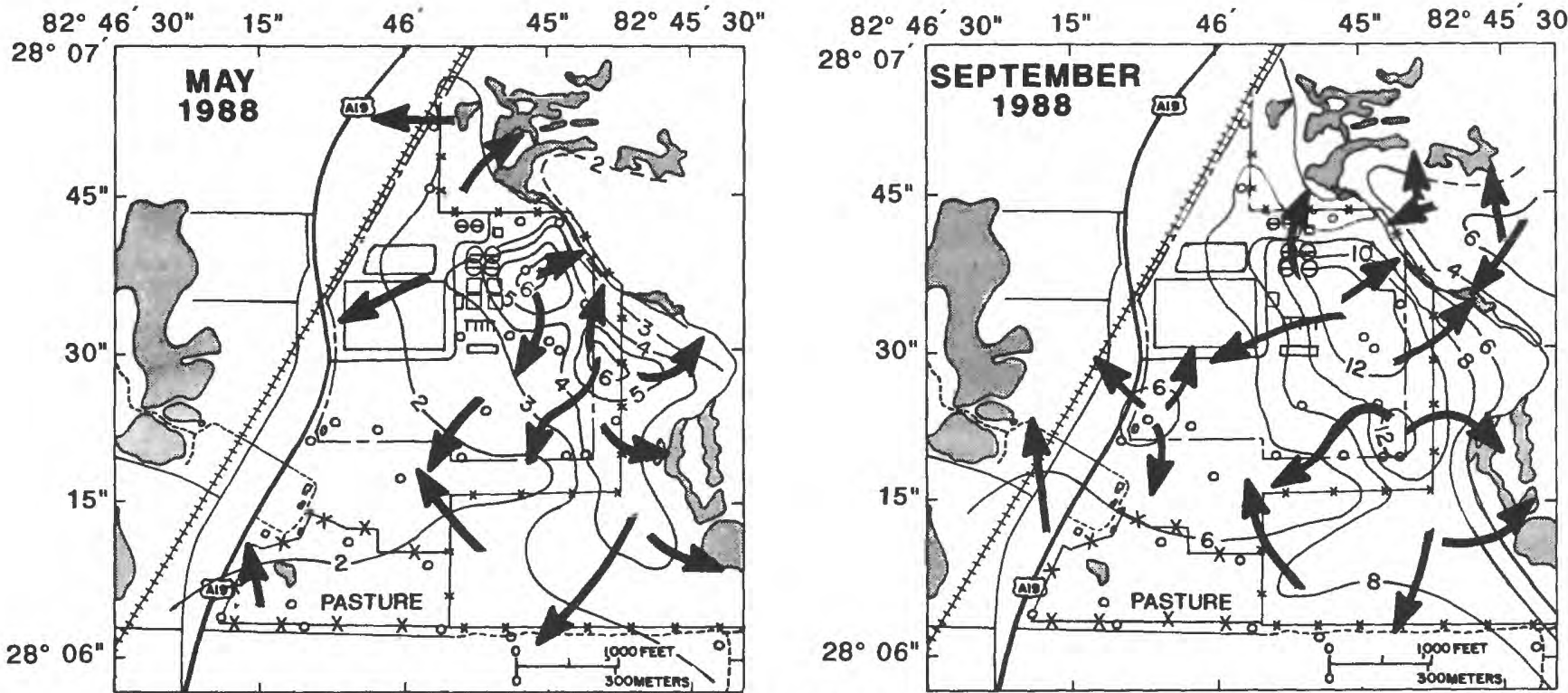

\section{EXPLANATION}

WATER-TABLE CONTOUR-- Shows altitude of water table of the surficial aquifer. Contour interval variable. Datum is sea level

FLOW PATH-- Arrow indicates the direction of ground-water flow

$\circ$

DATA-COLLECTION SITE

Figure 10. Configuration of the water table of the surficial aquifer and direction of ground-water flow, May and September 1988.
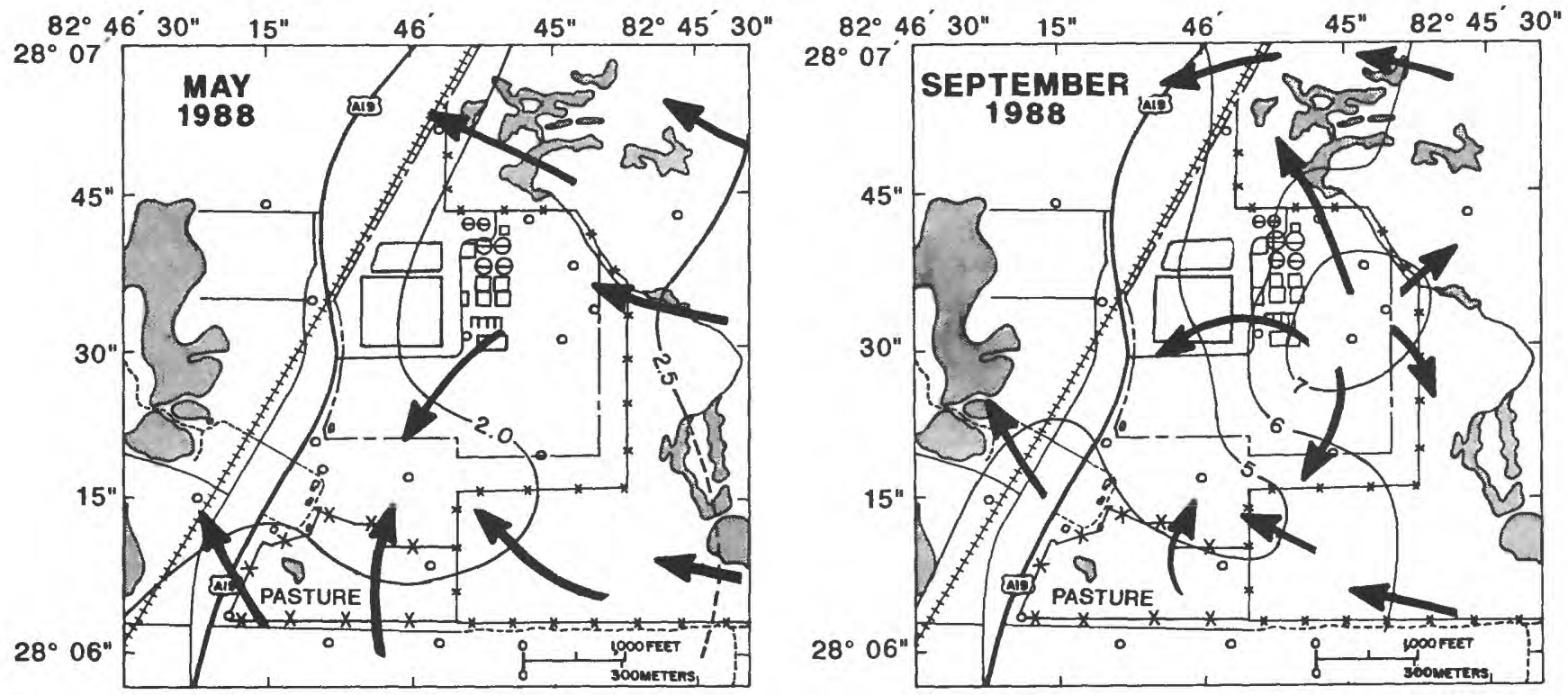

\section{EXPLANATION}

POTENTIOMETRIC SURFACE CONTOUR-- Shows altitude of potentiometric surface of the Upper Floridan aquifer. Contour interval variable. Datum is sea level

FLOW PATH-- Arrow indicates the direction of ground-water flow

- DATA-COLLECtion Site

Figure 11. Configuration of the potentiometric surface of the Upper Floridan aquifer and direction of ground-water flow, May and September 1988. 
The potentiometric surface of the Upper Floridan aquifer varies in altitude, generally being lowest in May during the dry season and highest in September at the end of the rainy season. The potentiometric surface in the area of the mound ranged from slightly more than $2 \mathrm{ft}$ above sea level in May 1988 to greater than $7 \mathrm{ft}$ above sea level in September 1988 and was generally about $1 \mathrm{ft}$ higher than in the surrounding areas. Regional ground-water flow in the Upper Floridan aquifer in the area of the study site generally is from east to west. At the disposal site, the ground-water trough and mound alter this direction of flow. During the dry period (May) when there is little or no mounding, water moves into the study area from the east, converges toward the trough, then turns west toward discharge points along the coast (fig. 11). In the northern part of the study area, the direction of flow continues generally toward the west. During the wet season (September) when mounding occurs, flow from the mound is radial. Water enters the study area from the east and is diverted by and mixed with the ground water flowing from the mound. Flow away from the mound area is similar to dry-season flow patterns, moving toward the coast in the north and converging toward the trough in the central and southern parts of the study area (fig. 11).

\section{Water Quality}

Water-quality data predating disposal operations exist for a few wells in the study area. Only one surficial aquifer well (20D) and one Upper Floridan aquifer well (20E) at site 38 have long-term water-quality data (table 5). Site 38 is on the edge of the topographic depression in the center of the disposal site (figs. 2 and 4). The surficial aquifer well is $12 \mathrm{ft}$ deep and is completed in the sand above the residuum layer. The Upper Floridan aquifer well is $27 \mathrm{ft}$ deep and is completed approximately $10 \mathrm{ft}$ below the top of the Tampa Limestone. During the study period, the wells were periodically inundated by ponded effluent during disposal activities. The discontinuous nature of the residuum layer and the rapid ponding of effluent in the vicinity of these wells caused water-quality changes to occur soon after disposal operations began.

Graphs of specific conductance and chloride concentrations in both wells show increasing trends since 1976 (fig. 12). During the period of record (1974-89), specific conductance increased from less than 100 to more than $1,200 \mu \mathrm{S} / \mathrm{cm}$ in the surficial aquifer and from about 300 to $1,100 \mu \mathrm{S} / \mathrm{cm}$ in the Upper Floridan aquifer. Chloride concentrations in water from the surficial aquifer well and the Upper Floridan aquifer well increased from less than 10 to about $180 \mathrm{mg} / \mathrm{L}$. Increases were greatest from 1976 to 1980 in the surficial aquifer and from 1976 to 1982 in the Upper Floridan aquifer (fig. 12). After 1982, water quality in both aquifers resembled that of the sprayed effluent. Since that time, specific conductance and chloride concentrations have remained relatively stable. Fluctuations in concentrations are due to the varying volumes of onsite effluent disposal and seasonal rainfall amounts. With the exception of ammonia and nitrate nitrogen, most water-quality constituents at site 38 have shown similar increases in concentrations (table 5).

The concentration of total nitrogen in water from both wells increased rapidly in response to the start of disposal operations. Although the dominant nitrogen species in the effluent is ammonia, the dominant species in samples from both wells, prior to 1987 , was nitrate, indicating nitrification was occurring. Nitrification is the process by which the nitrogen in ammonia is aerobically oxidized forming nitrite and then nitrate. From 1977 to 1989 , total nitrogen concentration has remained fairly consistent; however, in 1987, dominant species of nitrogen in the ground water at the site shifted to ammonia (table 5). The change from an oxidizing to a reducing environment indicates the system has become anaerobic and nitrification is not occurring. The anaerobic condition probably resulted from long-term inundation of the site and surrounding areas by ponded effluent due to heavy disposal operations during this time period.

\section{Initial Water-Quality Results}

Water-quality samples were collected in 1987 and 1988 from a limited number of sites to determine which constituents could be used as indicators of effluent movement. These samples were analyzed for major ions, nutrients, trace metals, MBAS, and organic compounds, including base-neutral and acid-extractable compounds, herbicides, insecticides, and VOC. The results of the major ion, nutrient, and MBAS analyses are listed in table 6.

Samples for analysis of coliform bacteria were collected from Wall Springs (fig. 2, site 1) and the private supply well at site 21 (fig. 2) only after the formation of a sinkhole at the disposal site partially drained the area of ponded effluent. These samples were collected because the sites lie along a ground-water flowpath from the sprayfield to the discharge point at Wall Springs. Water discharging from Wall Springs increased from less than 2 to $16 \mathrm{ft}^{3} / \mathrm{s}$ following the sinkhole formation. Within 2 weeks, discharge from the spring again dropped to near $2 \mathrm{ft}^{3} / \mathrm{s}$. During the same 2-week period (April 1 to April 15, 1988), the Upper Floridan aquifer wells at sites 19 and 24 (also along the same flowpath) had increasing then decreasing water levels; this behavior was not noted in any of the other Upper Floridan aquifer wells at the study site during this time period. Both samples contained low counts of unidentified bacteria; however, coliform bacteria were detected only in the sample from Wall Springs. 
An effluent sample collected on June 24, 1987, contained lindane, dieldrin, malathion, and 2,4-D in concentrations just above detection levels $(0.01 \mu \mathrm{g} / \mathrm{L})$. Diazinon and 1,4-dichlorbenzene also were found in the effluent sample at concentrations of 1.1 and $4.8 \mu \mathrm{g} / \mathrm{L}$, respectively. None of the above organic compounds, however, were found in ground-water samples. Seventeen ground-water samples from both aquifers, however, did contain concentrations of vinyl chloride, chloroform, toluene, tetrachloroethylene, and $1,1,1,-$ trichloroethane ranging from 0.03 to $16.0 \mu \mathrm{g} / \mathrm{L}$.
All concentrations were below the maximum contamination limits set by the Florida Department of Environmental Regulation (1989).

Because concentrations of most organic constituents found in the effluent or the ground-water samples were low, or could not be duplicated with any degree of regularity, they were eliminated from subsequent sampling. Metals and coliform bacteria samples also were eliminated from subsequent groundwater sampling because concentrations were low or these constituents were undetectable in the ground-water samples.

Table 5. Selected long-term water-quality data for wells at site 38

[Concentrations are in milligrams per liter, except where noted. $\mu \mathrm{S} / \mathrm{cm}$, microsiemens per centimeter; - , no data; $<$, less than]

$\begin{array}{cccccccc}\text { Date } & \begin{array}{c}\text { Specific } \\ \text { conductance } \\ (\mu \mathrm{S} / \mathrm{cm})\end{array} & \begin{array}{c}\mathrm{pH} \\ \text { (units) }\end{array} & \begin{array}{c}\text { Organic } \\ \text { nitrogen }\end{array} & \begin{array}{c}\text { Ammonia } \\ \text { nitrogen }\end{array} & \begin{array}{c}\text { Nitrate } \\ \text { nitrogen }\end{array}\end{array}$ Phosphorus Calcium Magnesium Sodium Potassium Chloride Sulfate

\begin{tabular}{|c|c|c|c|c|c|c|c|c|c|c|c|c|}
\hline \multirow[b]{2}{*}{$5-74$} & \multirow[b]{2}{*}{62} & \multirow[b]{2}{*}{5.1} & \multicolumn{10}{|c|}{ Surficial aquifer system well 280629082454204 - USGS NRSD well 20D } \\
\hline & & & 0.13 & 0.05 & 0.10 & 0.02 & 6.0 & 1.3 & 1.9 & 1.3 & 3.3 & - \\
\hline $3-76$ & 74 & - & .13 & .01 & .10 & .04 & 5.3 & 1.7 & 2.9 & .5 & 3.5 & 18 \\
\hline $6-77$ & 372 & 6.9 & .00 & $<.01$ & 21 & .02 & - & - & - & - & 48 & - \\
\hline $9-77$ & 395 & 5.9 & 1.3 & .05 & 7.3 & .16 & 6.0 & .7 & 64 & .7 & 55 & 33 \\
\hline $8-78$ & 388 & 7.0 & .18 & .02 & 4.1 & .12 & 58 & 2.9 & 13 & 1.0 & 39 & 18 \\
\hline $11-79$ & 590 & 6.2 & 1.3 & .00 & 11 & .02 & - & - & - & - & 84 & - \\
\hline $7-80$ & 660 & 6.1 & .93 & .02 & 22 & .11 & 23 & 5.0 & 95 & 1.0 & 120 & - \\
\hline $12-80$ & 920 & 7.2 & .71 & .01 & 5.5 & .02 & - & - & - & - & - & - \\
\hline $3-81$ & 860 & 7.2 & .88 & .04 & 10 & .06 & 60 & 8.4 & 120 & 6.3 & 140 & - \\
\hline $4-82$ & 849 & 6.8 & .72 & .02 & 3.7 & 3.5 & 44 & 6.8 & 110 & 11 & 120 & - \\
\hline $6-83$ & 850 & 7.1 & .54 & .02 & 5.2 & 3.2 & 49 & 6.0 & 91 & 13 & 130 & - \\
\hline $3-84$ & 820 & 7.3 & .74 & .02 & 7.5 & 3.3 & 53 & 7.3 & 94 & 7.8 & - & - \\
\hline $8-84$ & 870 & 7.0 & .52 & .02 & 2.0 & 2.8 & 57 & 6.8 & 110 & 13 & 120 & - \\
\hline $6-85$ & 765 & 7.2 & .58 & .03 & 4.4 & 2.6 & 42 & 5.2 & 98 & 4.9 & - & - \\
\hline $4-86$ & 891 & 7.0 & .03 & .07 & .96 & .16 & 52 & 5.3 & 120 & 5.9 & - & - \\
\hline $6-87$ & 1,040 & 7.0 & 1.5 & 4.7 & $<.02$ & 3.9 & 80 & 8.0 & 130 & 16 & 170 & 28 \\
\hline $8-88$ & 923 & 7.5 & 1.0 & 2.8 & $<.02$ & 3.4 & 44 & 4.5 & 124 & 21 & 160 & 35 \\
\hline \multirow[t]{2}{*}{$4-89$} & 1,230 & 7.4 & 1.0 & 21 & $<.02$ & 7.0 & 66 & 5.6 & 140 & 40 & 180 & 17 \\
\hline & \multicolumn{12}{|c|}{ Upper Floridan aquifer well 280629082454205 - USGS FLRD well $20 \mathrm{E}$} \\
\hline $5-74$ & 311 & 6.0 & 0.16 & 0.13 & 0.16 & 0.49 & 51 & 3.3 & 5.4 & 0.9 & 7.2 & - \\
\hline $3-76$ & 229 & - & .03 & .07 & .24 & .18 & 39 & 2.2 & 4.8 & .7 & 6.0 & 18 \\
\hline $6-77$ & 270 & 6.3 & .00 & $<.02$ & 1.4 & .18 & 46 & 2.5 & 6.8 & .7 & 20 & 18 \\
\hline $9-77$ & 305 & 7.6 & .20 & .07 & 1.1 & .20 & 48 & 2.6 & 7.1 & .9 & 19 & 16 \\
\hline $8-78$ & 621 & 5.2 & .60 & .02 & 20 & .13 & 10 & 1.6 & 100 & 9.0 & 97 & 43 \\
\hline $11-79$ & 500 & 7.0 & .48 & .02 & 4.5 & .05 & - & - & - & - & 63 & - \\
\hline $7-80$ & 580 & 6.4 & .44 & .02 & 8.2 & .13 & 73 & 4.0 & 34 & 1.5 & 90 & - \\
\hline $12-80$ & 610 & - & .22 & .02 & 5.5 & .07 & - & - & - & - & - & - \\
\hline $3-81$ & 625 & 6.0 & .56 & .02 & 6.2 & .08 & 86 & 9.0 & 34 & 1.6 & 96 & - \\
\hline $4-82$ & 900 & 6.5 & .26 & .02 & 6.4 & .22 & 110 & 6.2 & 66 & 2.6 & 150 & - \\
\hline $6-83$ & 995 & 7.3 & .17 & .04 & 3.5 & .18 & 100 & 6.1 & 63 & 2.0 & 140 & - \\
\hline $3-84$ & 870 & 7.5 & .19 & .02 & 3.2 & .21 & 100 & 5.9 & 54 & 1.7 & - & - \\
\hline $8-84$ & 850 & 7.1 & .11 & .01 & 1.9 & .23 & 98 & 5.7 & 56 & 1.7 & - & - \\
\hline $6-85$ & 890 & 7.1 & .00 & 4.2 & 1.4 & .60 & 100 & 6.0 & 57 & 3.7 & - & - \\
\hline $4-86$ & 960 & 7.4 & .30 & 1.9 & .19 & .31 & 100 & 6.0 & 89 & 2.6 & - & - \\
\hline $6-87$ & 1,000 & 7.2 & .50 & 1.1 & $<.02$ & 1.2 & 77 & 7.1 & 120 & 7.6 & 150 & 18 \\
\hline $8-88$ & 1,050 & 7.2 & .20 & 3.6 & $<.02$ & 2.3 & 64 & 6.2 & 130 & 14 & 150 & 30 \\
\hline $4-89$ & 1,120 & 7.4 & 1.0 & 10.0 & $<.02$ & 2.8 & 74 & 7.0 & 120 & 28 & 170 & 16 \\
\hline
\end{tabular}




\section{Distribution of Water-Quality Constituents in the} Surficial Aquifer

Water-quality samples were collected from 1 surfacewater site and 40 wells during March and April 1989 to characterize water quality in the surficial aquifer and to determine which areas of the aquifer have been affected by disposal operations. Water-quality analyses were limited to field measurements, major ions, nutrients, and MBAS. Additional analyses for stable nitrogen isotopes were made to identify treated sewage or nitrogen fertilizers as the source of high nitrogen concentrations in parts of the study area. Results of the analyses are listed in table 7.

Sprayed effluent percolating downward through the unsaturated deposits transports various chemical constituents into the ground water. Contours of decreasing concentrations, or boundaries delineating the extent of high concentrations (figs. 13, 15, 16, and 17), indicate that various chemical constituents are present and have moved downgradient with the ground water. The same general distribution patterns are indicated in all the figures. Water that contains higher concentrations of some constituents is present in areas that receive effluent and closely correspond to the ground-water mound area. Lower concentrations are present west of the disposal site in areas that correspond to the ground-water trough where effluent-influenced ground water discharges to the Upper Floridan aquifer through discontinuities in the residuum layer. Distribution of water-quality constituents closely follows the ground-water flow paths in the study area.

The specific conductance of water in the surficial aquifer during March and April 1989 is shown in figure 13. In general, specific conductance of ground water within the study area ranged from 110 to $1,150 \mu \mathrm{S} / \mathrm{cm}$ (the mean specific conductance of the effluent was $1,100 \mu \mathrm{S} / \mathrm{cm}$ ). The $800-\mu \mathrm{S} / \mathrm{cm}$ line of equal specific conductance in figure 13 approximately delineates the areas of the disposal site and the golf courses that receive effluent. The areas of the grove, south and southwest of the disposal site, and the pastureland, west of the golf course (fig. 1), have specific-conductance values that range from 110 to $536 \mu \mathrm{S} / \mathrm{cm}$, with a mean value of $300 \mu \mathrm{S} / \mathrm{cm}$. These areas correspond to the area underlain by the large ground-water trough. In general, the area northwest of the disposal site has a relatively uniform distribution of specific-conductance values that range between 600 and $800 \mu \mathrm{S} / \mathrm{cm}$.

Well site 62 had an unusually high specific conductance. This site is just north of the original effluent holding pond on the western edge of an area formerly used for drying sludge (fig. 2). Eleven specific-conductance measurements were made on samples from this well since January 1988.

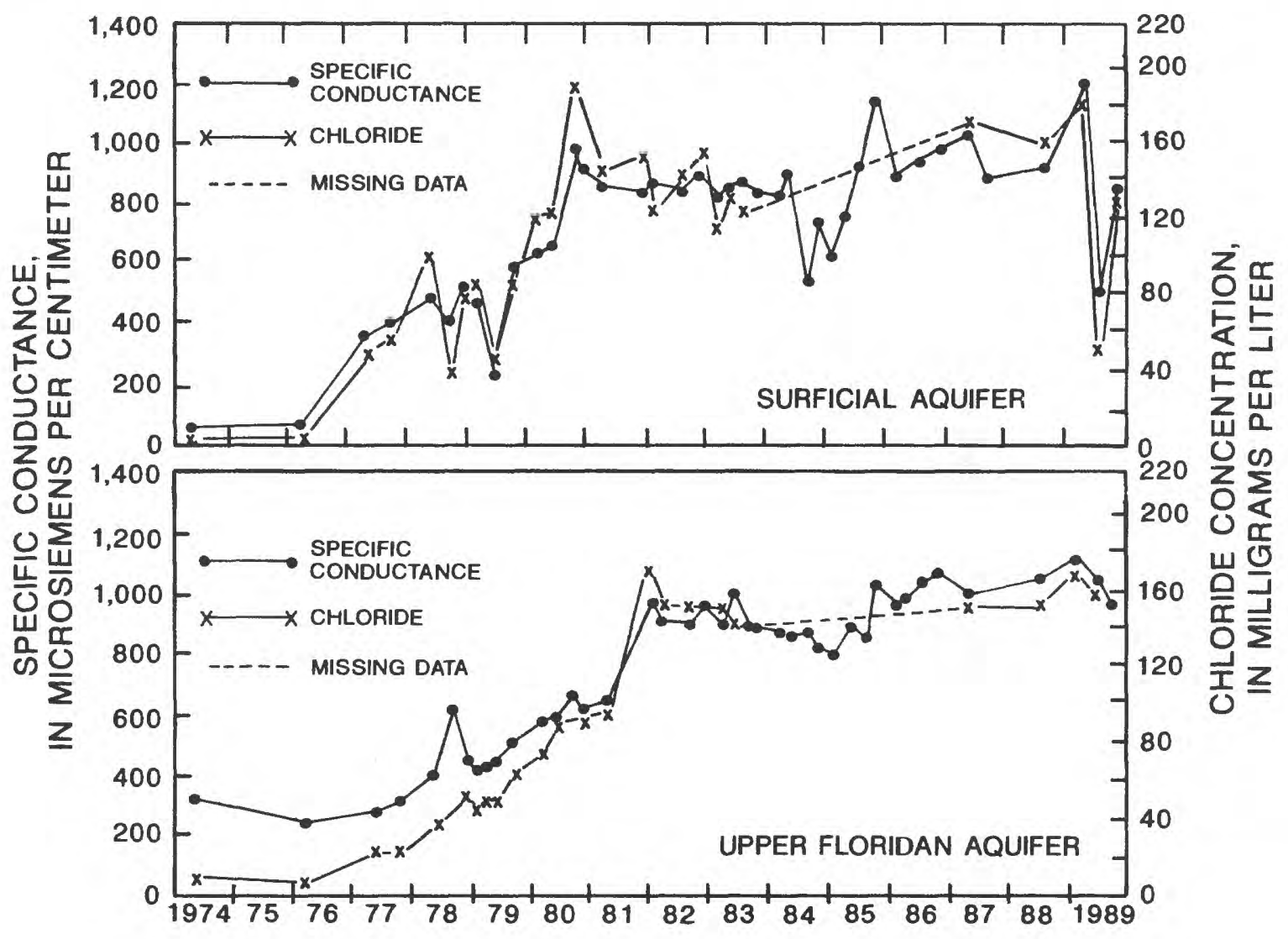

Figure 12. Specific conductance and chloride concentrations of water from the surficial aquifer and Upper Floridan aquifer at well site 38, 1974-89. 
Table 6. Summary of selected water-quality data for sites in the surficial and Upper Floridan aquifers, 1987-88

[Concentrations are in milligrams per liter, except as noted. $\mu \mathrm{S} / \mathrm{cm}$, microsiemens per centimeter; MBAS, methylene blue active substance; _, no data; $<$, less than]

\begin{tabular}{|c|c|c|c|c|c|c|c|c|c|c|c|c|c|c|}
\hline $\begin{array}{l}\text { Map } \\
\text { No. }{ }^{1}\end{array}$ & Date & $\begin{array}{c}\text { Specific } \\
\text { conductance } \\
(\mu \mathrm{S} / \mathrm{cm})\end{array}$ & $\begin{array}{c}\mathrm{pH} \\
\text { (units) }\end{array}$ & $\begin{array}{l}\text { Organic } \\
\text { nitrogen }\end{array}$ & $\begin{array}{l}\text { Ammonia } \\
\text { nitrogen }\end{array}$ & $\begin{array}{l}\text { Nitrate } \\
\text { nitrogen }\end{array}$ & $\begin{array}{l}\text { Phos- } \\
\text { phorus }\end{array}$ & Calcium & $\begin{array}{l}\text { Magne- } \\
\text { sium }\end{array}$ & Sodium & $\begin{array}{l}\text { Potas- } \\
\text { sium }\end{array}$ & $\begin{array}{l}\text { Chlo- } \\
\text { ride }\end{array}$ & $\begin{array}{l}\text { Sul- } \\
\text { fate }\end{array}$ & MBAS \\
\hline
\end{tabular}

\begin{tabular}{|c|c|c|c|c|c|c|c|c|c|c|c|c|c|c|}
\hline \multirow[b]{2}{*}{6} & \multirow[b]{2}{*}{$6-87$} & \multirow[b]{2}{*}{1,320} & \multirow[b]{2}{*}{7.6} & \multirow[b]{2}{*}{4.2} & \multicolumn{5}{|c|}{ Surficial aquifer wells or surface-water sites } & \multirow[b]{2}{*}{82} & \multirow[b]{2}{*}{30} & \multirow[b]{2}{*}{160} & \multirow[b]{2}{*}{120} & \multirow[b]{2}{*}{ - } \\
\hline & & & & & 0.05 & 31 & 14 & 90 & 36 & & & & & \\
\hline \multirow[t]{2}{*}{23} & $6-87$ & 179 & 4.6 & .17 & .03 & 7.1 & .04 & 14 & 1.9 & 5.9 & 1.2 & 13 & 27 & 0.08 \\
\hline & $8-88$ & 181 & 4.4 & .43 & .02 & 6.2 & .04 & 13 & 1.6 & 6.0 & 1.2 & 12 & 28 & .09 \\
\hline 31 & $6-87$ & 185 & 4.9 & 2.7 & 13 & 1.8 & .85 & 8.4 & 2.1 & 6.0 & 5.9 & 10 & 10 & .08 \\
\hline 35 & $7-87$ & 753 & 6.9 & 2.0 & .77 & .01 & .65 & 54 & 3.9 & 98 & 3.2 & 120 & 23 & .06 \\
\hline 38 & $6-87$ & 1,040 & 7.0 & - & - & - & - & 80 & 7.9 & 130 & 16 & 170 & 28 & .12 \\
\hline 42 & $4-88$ & 1,080 & 7.3 & 4.2 & 6.8 & .01 & 7.4 & 68 & 6.5 & 130 & 22 & 160 & 17 & .28 \\
\hline \multirow[t]{2}{*}{47} & $6-87$ & 705 & 6.4 & 1.1 & .35 & 11 & .08 & 19 & 5.4 & 82 & 12 & 80 & 88 & .10 \\
\hline & $8-88$ & 800 & 5.8 & .99 & .11 & 11 & .04 & 27 & 7.3 & 110 & 19 & 130 & 75 & .19 \\
\hline \multirow[t]{2}{*}{61} & $6-87$ & 1,080 & 7.5 & 5.1 & .97 & 6.5 & 6.2 & 65 & 6.0 & 140 & 12 & 170 & 29 & .20 \\
\hline & $6-88$ & 1,120 & 7.7 & 2.3 & 8.7 & 1.1 & 4.3 & 68 & 5.6 & 130 & 21 & 180 & 34 & .26 \\
\hline \multicolumn{15}{|c|}{ Upper Floridan aquifer wells or springs } \\
\hline \multirow[t]{3}{*}{1} & $6-87$ & 1.645 & 7.9 & 0.18 & 0.02 & 9.4 & 0.46 & 80 & 25 & 210 & 13 & 360 & 84 & 0.17 \\
\hline & $4-88$ & 1,420 & 7.5 & .21 & .16 & 9.4 & .36 & 79 & 21 & 160 & 11 & 250 & 71 & .18 \\
\hline & $8-88$ & 1,750 & 7.2 & .42 & .15 & 13 & .37 & 80 & 28 & 220 & 13 & 390 & 82 & .19 \\
\hline \multirow[t]{2}{*}{2} & $6-87$ & 1,660 & 8.3 & .18 & .02 & 1.6 & .04 & 68 & 26 & 120 & 8.3 & 440 & 65 & .03 \\
\hline & $6-88$ & 1,360 & 8.1 & .61 & .02 & 2.0 & .04 & 58 & 22 & 170 & 6.6 & 290 & 45 & - \\
\hline 3 & $6-88$ & 2,380 & 8.0 & $<.20$ & .03 & 3.9 & .02 & 90 & 32 & 390 & 7.5 & 620 & 110 & - \\
\hline \multirow[t]{2}{*}{15} & $6-87$ & 1,770 & 7.8 & .19 & .02 & 1.7 & .05 & 100 & 24 & 220 & 10 & 430 & 86 & - \\
\hline & $6-88$ & 513 & 7.9 & $<.20$ & .03 & .88 & .56 & 69 & 4.6 & 37 & 4.6 & 46 & 29 & - \\
\hline 19 & $7-87$ & 1,830 & 7.9 & .18 & $<.01$ & 12 & .20 & 74 & 33 & 250 & 18 & 410 & 96 & .15 \\
\hline 21 & $4-88$. & 582 & 7.9 & $<.20$ & $<.01$ & 7.1 & .30 & 49 & 13 & 42 & 8.6 & 58 & 53 & .10 \\
\hline \multirow[t]{2}{*}{38} & $6-87$ & 1,000 & 7.5 & .50 & 1.1 & .01 & 1.2 & 77 & 7.1 & 120 & 7.6 & 150 & 18 & .19 \\
\hline & $8-88$ & 1,050 & 7.2 & .20 & 3.6 & .01 & 2.3 & 64 & 5.7 & 130 & 22 & 160 & 17 & .20 \\
\hline 45 & $6-87$ & 5,400 & 7.7 & .07 & .13 & .01 & .18 & 90 & 90 & 860 & 36 & 1.500 & 240 & .17 \\
\hline 52 & $6-88$ & 425 & 7.6 & $<.20$ & .02 & 2.8 & .06 & 50 & 6.1 & 23 & 2.6 & 30 & 28 & - \\
\hline 57 & $6-87$ & 935 & 8.0 & .19 & .01 & 5.6 & .09 & 98 & 9.7 & 62 & 2.4 & 120 & 62 & - \\
\hline 64 & $6-87$ & 509 & 8.4 & - & - & - & - & 60 & 7.2 & 31 & 2.1 & 50 & 20 & .03 \\
\hline
\end{tabular}

'Locations of sampling sites are shown in figure 2.

Although sludge has not been deposited in these drying beds since December 1987, specific-conductance values at this well have risen steadily from 1,100 (January 1988) to 3,100 $\mu \mathrm{S} / \mathrm{cm}$ (June 1989). Subsequently, a drive-point sampler was used to collect nine additional samples to determine the extent of the high values of specific conductance. The maximum depth penetrated with the drive-point sampler was $22 \mathrm{ft}$ below land surface (fig. 14).

Although specific-conductance values at site 62 are high in the immediate well area, values decrease rapidly at short distances from the well. Hydrogeologic section $D-D^{\prime}$ (fig. 14) shows the distribution of specific-conductance values along a 300 -ft east-west line through the well. About $100 \mathrm{ft}$ west of the well, specific conductance dropped to $21 \mu \mathrm{S} / \mathrm{cm}$ at the water table and $220 \mu \mathrm{S} / \mathrm{cm} 3 \mathrm{ft}$ below the water table. Within $250 \mathrm{ft}$ east of the well at site 62 , specificconductance values drop to less than $1,500 \mu \mathrm{S} / \mathrm{cm}$. Hydrogeologic section $E-E^{\prime}$ (fig. 14) shows the distribution of specific-conductance values along a 185 -ft line running parallel to the old railroad bed, starting $50 \mathrm{ft}$ north of a point $30 \mathrm{ft}$ west of the well at site 62 (fig. 2). Specific conductance increases to more than $1,800 \mu \mathrm{S} / \mathrm{cm}$ about $110 \mathrm{ft}$ south of the starting point, then decreases slowly toward the south. GPR records indicate the absence of the residuum layer and the probability of a paleosinkhole in the area west of well site 62 where lower specific conductance occurs.

The distribution of sodium and chloride (fig. 15) is similar to the distribution of specific conductance. Sodium and chloride behave conservatively (unreactive), moving through the aquifer with the ground water. In the surficial aquifer, sodium and chloride can be used as indicators of the area affected by disposal operations. Sodium and chloride concentrations in the surficial aquifer range from 2.3 to 140 $\mathrm{mg} / \mathrm{L}$ and 2.4 to $190 \mathrm{mg} / \mathrm{L}$, respectively. The highest concentrations are in the area of the ground-water mound and the lowest concentrations are in the area of the ground-water 
trough (fig. 10). The area underlying the original effluent holding pond and the old sludge drying beds (fig. 1) also contains sodium and chloride concentrations similar to concentrations found in the effluent. Effluent disposal had not occurred in this area prior to sampling. The high concentrations are probably due to previous sludge disposal and possible leakage from the original effluent holding pond.
Dissolved nitrate is the only constituent that has concentrations exceeding maximum allowable limits in the study area; $10 \mathrm{mg} / \mathrm{L}$ nitrate as nitrogen is the maximum allowable limit for drinking water set by the Florida Department of Environmental Regulation (1989). Nitrate is extremely soluble and, when application rates and concentrations exceed the needs of plants, will move past the root zone and

Table 7. Summary of selected water-quality data for sites in the surficial aquifer, March and April 1989

IConcentrations are in milligrams per liter, except as noted; $\mu \mathrm{S} / \mathrm{cm}$, microsiemens per centimeter; MBAS, methylene blue active substance, ppt, parts per thousand; -, no data; <, less than]

\begin{tabular}{|c|c|c|c|c|c|c|c|c|c|c|c|c|c|c|}
\hline $\begin{array}{l}\text { Map } \\
\text { No.' }\end{array}$ & $\begin{array}{c}\text { Specific } \\
\text { conductance } \\
(\mu \mathrm{S} / \mathrm{cm})\end{array}$ & $\underset{\text { (units) }}{\mathrm{pH}}$ & $\begin{array}{c}\text { Ammonia } \\
\text { nitrogen } \\
\text { (as N) }\end{array}$ & $\begin{array}{c}\text { Nitrate } \\
\text { nitrogen } \\
\text { (as } \mathrm{N} \text { ) }\end{array}$ & $\begin{array}{l}\delta^{15} \mathrm{~N} \\
(\mathrm{ppt})\end{array}$ & $\begin{array}{c}\text { Total } \\
\text { phosporus } \\
\text { (as P) }\end{array}$ & $\begin{array}{l}\text { Calcium } \\
\text { (dis- } \\
\text { solved) }\end{array}$ & $\begin{array}{l}\text { Magnesium } \\
\text { (dis- } \\
\text { solved) }\end{array}$ & $\begin{array}{l}\text { Sodium } \\
\text { (dis- } \\
\text { solved) }\end{array}$ & $\begin{array}{l}\text { Potassium } \\
\text { (dis- } \\
\text { solved) }\end{array}$ & $\begin{array}{l}\text { Alka- } \\
\text { linity }\end{array}$ & $\begin{array}{l}\text { Chloride } \\
\text { (dis- } \\
\text { solved) }\end{array}$ & $\begin{array}{l}\text { Sulfate } \\
\text { (dis- } \\
\text { solved) }\end{array}$ & MBAS \\
\hline 6 & 1,196 & 7.0 & $<.01$ & 22 & 3.3 & .10 & 90 & 23 & 100 & 30 & 136 & 130 & 100 & .21 \\
\hline 7 & 334 & 6.8 & $<.01$ & .57 & 4.6 & .15 & 45 & 2.9 & 14 & .60 & 90 & 17 & 26 & .01 \\
\hline 8 & 330 & 6.7 & .02 & .88 & - & .26 & 44 & 5.8 & 3.7 & 8.5 & 126 & 5.0 & 7.5 & .09 \\
\hline 10 & 313 & 5.0 & 1.6 & .02 & - & .22 & 31 & 3.6 & 10 & 6.8 & 5.8 & 47 & 50 & .08 \\
\hline 14 & 390 & 7.0 & .01 & .68 & 24.3 & .67 & 72 & 3.6 & 4.6 & 1.9 & 182 & 11 & 24 & .05 \\
\hline 16 & 1,020 & 5.0 & $<.01$ & 28 & 5.2 & .05 & 36 & 18 & 98 & 24 & 7.0 & 130 & 130 & .36 \\
\hline 17 & 649 & 5.1 & $<.01$ & 6 & 3.0 & .25 & 17 & 7.2 & 82 & 12 & 2.5 & 120 & 78 & .29 \\
\hline 18 & 150 & 4.7 & $<.01$ & .52 & 4.0 & 1.1 & 3.8 & 1.5 & 13 & 4.8 & $<.1$ & 12 & 32 & .12 \\
\hline 19 & 419 & 6.9 & $<.01$ & 19 & 4.6 & .08 & 50 & 9.4 & 32 & 12 & 55 & 19 & 49 & .15 \\
\hline 26 & 220 & 4.3 & $<.01$ & 2.9 & 9.9 & .39 & 9.3 & 1.2 & 23 & 2.0 & $<.1$ & 30 & 32 & .06 \\
\hline 27 & 220 & 5.4 & $<.01$ & 9.4 & 10.7 & .01 & 11 & 2.3 & 16 & 3.4 & 5.0 & 7.0 & 30 & .14 \\
\hline 29 & 938 & 7.4 & $<.01$ & 5.6 & 7.1 & 2.5 & 59 & 5.6 & 120 & 24 & 179 & 160 & 36 & .12 \\
\hline 30 & 671 & 4.9 & $<.01$ & 41 & 6.9 & $<.02$ & 60 & 5.8 & 3.2 & 10 & 4.0 & 6.7 & 42 & .61 \\
\hline 31 & 648 & 6.2 & 1.3 & 6 & 14.7 & .36 & 13 & 2.2 & 98 & 4.2 & 6.9 & 140 & 46 & .15 \\
\hline 32 & 110 & 5.7 & $<.01$ & .14 & - & .03 & 41 & 1.6 & 4.8 & 1.5 & 16 & 7.9 & 13 & .08 \\
\hline 33 & 1,020 & 7.4 & $<.01$ & 16 & 11.9 & 4.6 & 67 & 5.9 & 130 & 26 & 179 & 160 & 36 & .21 \\
\hline 34 & 859 & 7.2 & 1.8 & .18 & - & 3.4 & 63 & 5.2 & 92 & 23 & 205 & 130 & 24 & .22 \\
\hline 35 & 860 & 6.4 & .53 & .05 & - & .05 & 110 & 3.3 & 62 & 1.7 & 296 & 95 & 2.0 & .07 \\
\hline 36 & 661 & 4.6 & .05 & 20 & 2.3 & .01 & 22 & 15 & 4.8 & 34 & .3 & 30 & 55 & .12 \\
\hline 38 & 1,150 & 7.4 & 21 & $<.02$ & - & 7 & 66 & 5.6 & 140 & 40 & 215 & 180 & 17 & - \\
\hline 43 & 998 & 7.6 & 5.5 & .02 & - & 5.4 & 67 & 6.1 & 120 & 32 & 239 & 160 & 24 & .27 \\
\hline 58 & 1,010 & 6.8 & .04 & 2.3 & 30.2 & 2.2 & 70 & 6.1 & 120 & 22 & 231 & 150 & 33 & .18 \\
\hline 59 & 724 & 5.6 & $<.01$ & 11 & 18.7 & .22 & 12 & 3.3 & 120 & 9.7 & 239 & 140 & 42 & .18 \\
\hline 60 & 748 & 5.0 & .29 & .03 & - & .09 & 12 & 5.6 & 120 & 5.3 & 7.4 & 190 & 40 & .15 \\
\hline 62 & 2,020 & 5.9 & 29 & 140 & 19.5 & 6.1 & 160 & 30 & 90 & 84 & 58 & 65 & 250 & 1.80 \\
\hline 65 & 661 & 7.3 & .19 & .02 & - & 33 & 70 & 15 & 60 & 7.4 & 136 & 25 & 3.9 & .05 \\
\hline
\end{tabular}

'Site locations are shown in figure 2. 


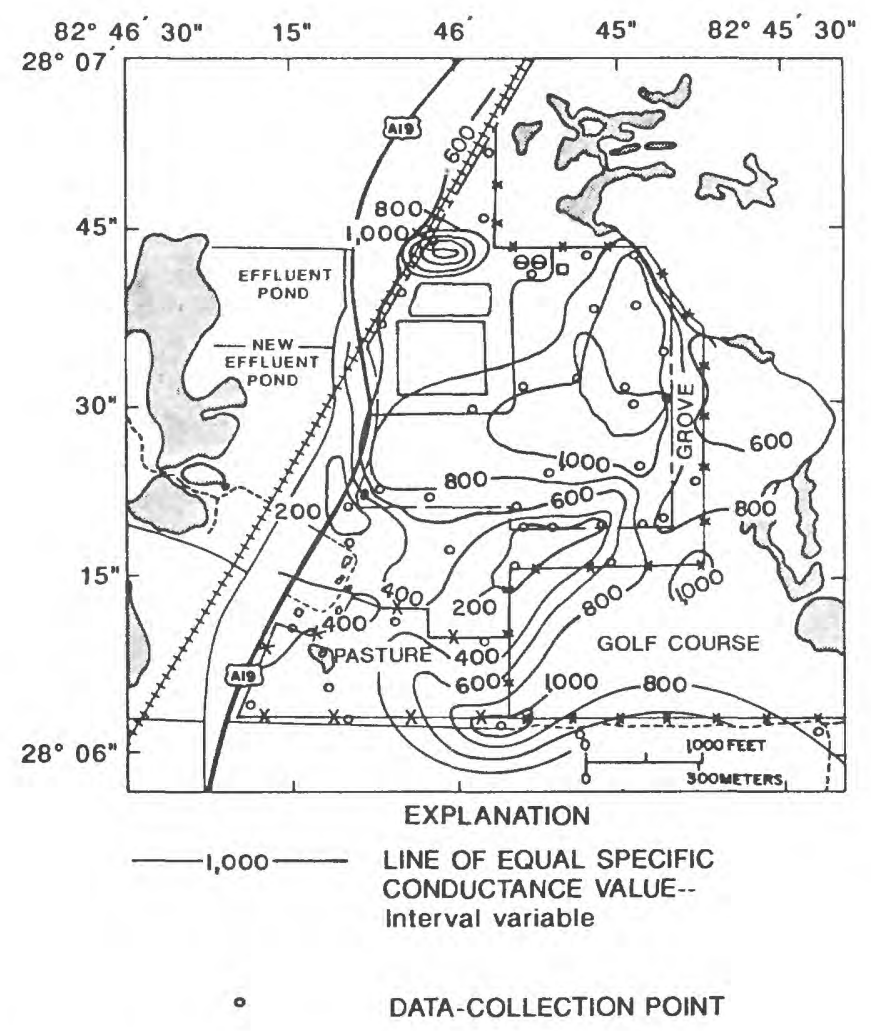

Figure 13. Specific conductance of water from the surficial aquifer, March and April 1989

percolate to the water table. The distribution of nitrate is shown in figure 16. Because of the nature of the surficial deposits at the study area and the resulting rapid movement past the root zone, nitrate has the same general distribution pattern as sodium, chloride, and specific conductance. Concentrations range from less than 1 to $140 \mathrm{mg} / \mathrm{L}$. Nitrate-nitrogen concentrations greater than $10 \mathrm{mg} / \mathrm{L}$ generally are found in areas that underlie the disposal site and the golf course.

The highest concentrations of nitrate occur at well sites 30 and 62 (fig. 2). Both well sites are at the edge of areas previously used as sludge drying beds (fig. 1). Samples from well sites 30 and 62 contained 41 and 140 $\mathrm{mg} / \mathrm{L}$ of nitrate, respectively. Sludge disposal in the area of well site 62 ended in December 1988. Effluent had not been disposed of at this site prior to sampling. Well site 30 is at the edge of the ground-water trough in an area that has been receiving effluent since mid-1988. The area has not been used for sludge disposal since late 1987. The lower nitrate concentration at well site 30 probably is due to dilution by the applied effluent, which is caused by the convergence and mixing of ground-water in the vicinity of the ground-water trough.
The comparison of nitrogen-isotope ratios $\left(\delta^{15} \mathrm{~N}\right)$ in nitrate can be an effective method for identifying sources of nitrogen in ground water. The $\delta^{15} \mathrm{~N}$ value is expressed as parts per thousand and is derived by comparing the ratio of ${ }^{14} \mathrm{~N}$ and ${ }^{15} \mathrm{~N}$ of nitrogen in a sample against the ratio of a known standard (atmospheric nitrogen). Kreitler (1975) and Kreitler and others (1978) found that ranges of $\delta^{15} \mathrm{~N}$ values could be used to identify sources of nitrate in ground water in areas where the primary sources of nitrate contamination were known. They reported that $\delta^{15} \mathrm{~N}$ values greater than $+10 \mathrm{ppt}$ (parts per thousand) were indicative of animal sources, -3 to $+2 \mathrm{ppt}$ were indicative of inorganic fertilizer sources, and +2 to $+8 \mathrm{ppt}$ were indicative of organic soil nitrogen sources.

Using these assumptions, nitrogen isotope samples were collected to determine whether the primary source of high nitrate concentrations in the study area was from the effluent or from fertilizers used at the resort golf course. Figure 16 shows the distribution of $\delta^{15} \mathrm{~N}$ values in the surficial aquifer. Nitrogen isotope ratios were greater than $+10 \mathrm{ppt}$ $\left({ }^{15} \mathrm{~N}\right.$ enriched) in areas of the disposal site that are receiving effluent, in the area that underlies the original effluent holding pond and nearby sludge drying beds, and in a small area 


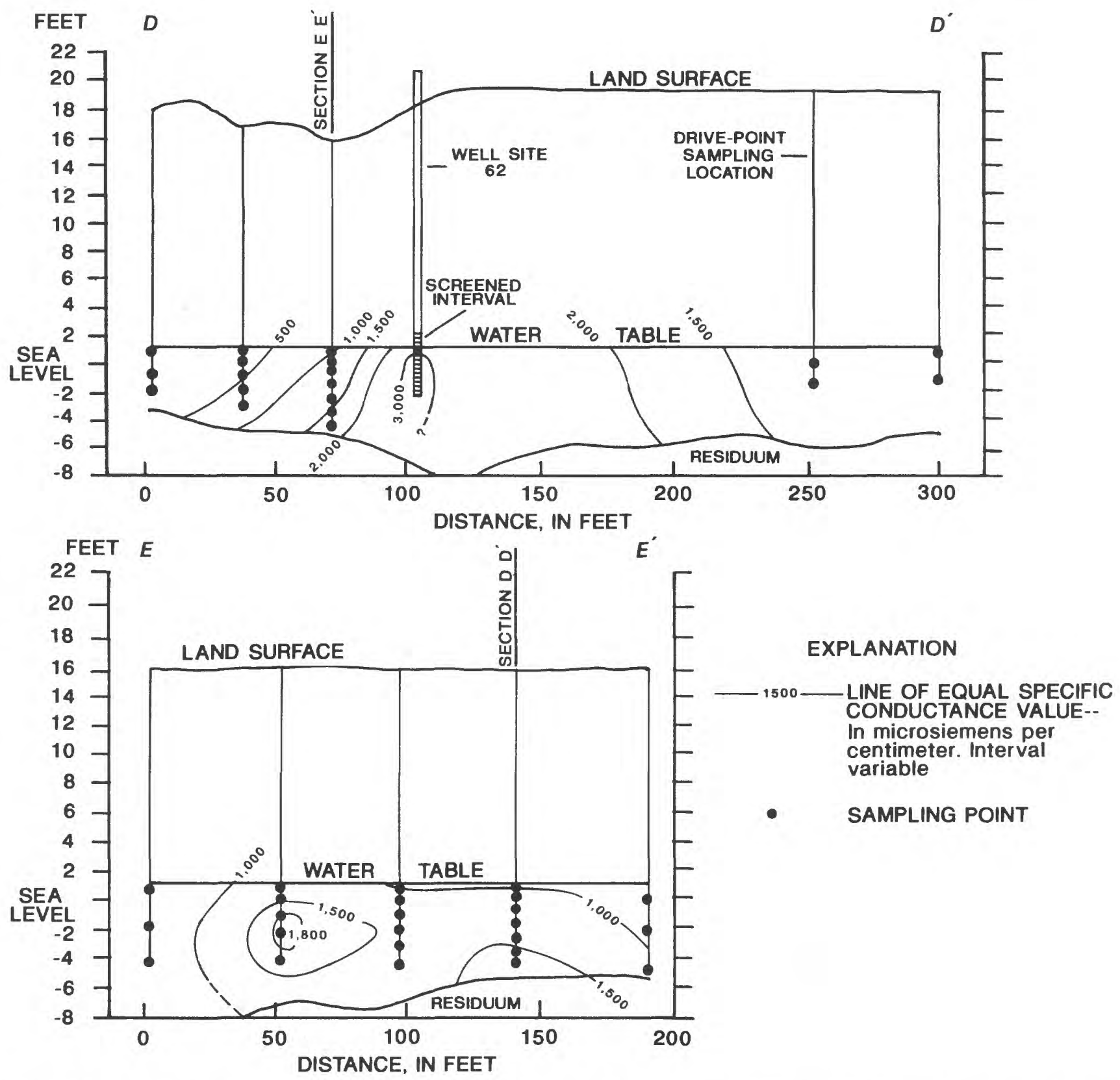

Figure 14. Specific conductance of ground water along hydrogeologic sections $D-D^{\prime}$ and $E-E^{\prime}$. (Trace of sections is shown in fig. 2.)

around well site 14 along the northern boundary of the pasture. The $\delta^{15} \mathrm{~N}$ value of nitrates in these areas ranged from +10.7 to $+30.2 \mathrm{ppt}$. In the area underlying the sprayfield, the distribution of ${ }^{15} \mathrm{~N}$-enriched water, corresponding to areas of high nitrate concentration, indicates the source of the nitrate to be the effluent. The ${ }^{15} \mathrm{~N}$-enriched samples in the area of the original effluent holding pond and old sludge drying beds indicate that sludge disposal and possible leakage from the holding pond may be the source of the high nitrate concentration. Although nitrate concentration was low $(0.66 \mathrm{mg} / \mathrm{L})$ in a ground-water sample from site 14 , the sample was ${ }^{15} \mathrm{~N}$ enriched $(+24.3 \mathrm{ppt})$. Flow patterns in the vicinity of the well indicate that it is not likely to be affected by effluent disposal. The most likely source of ${ }^{15} \mathrm{~N}$-enriched water is from livestock pastured at the site.

Samples from sites 6, 12, 16, 17, and 18 indicate that water in the surficial aquifer underlying the resort golf course is not highly ${ }^{15} \mathrm{~N}$ enriched, even though it is periodically irrigated with effluent, and nitrate concentrations in the aquifer are high. The $\delta^{15} \mathrm{~N}$ values ranged from +2.5 to $+5.2 \mathrm{ppt}$. Fertilizer is applied to the golf course fairways three times a year at a rate of $600 \mathrm{lb} / \mathrm{acre}$. The remaining parts of the golf 

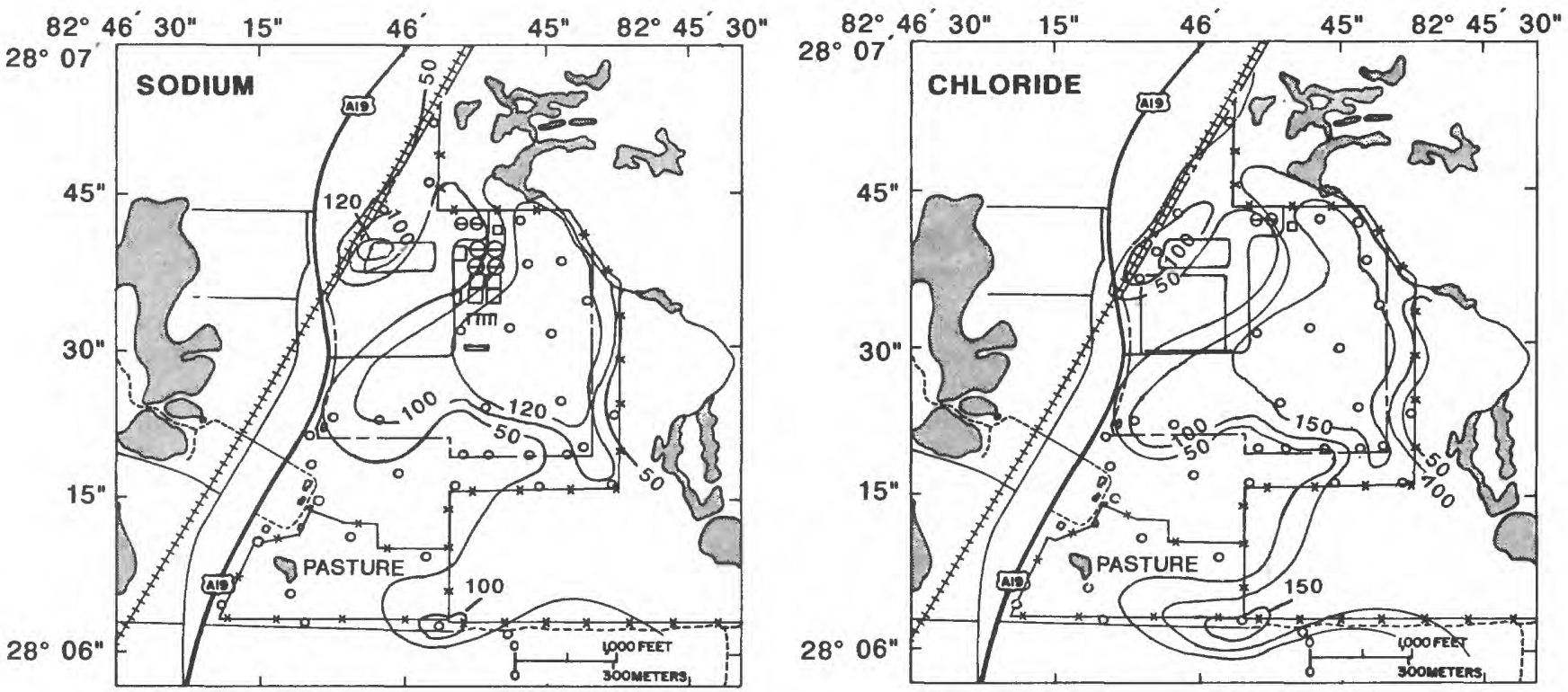

\section{EXPLANATION}

LINE OF EQUAL CONCENTRATION--

In milligrams per liter. Contour

interval variable

DATA-COLLECTION SITE

Figure 15. Distribution of sodium and chloride concentrations in water from the surficial aquifer, March and April 1989.

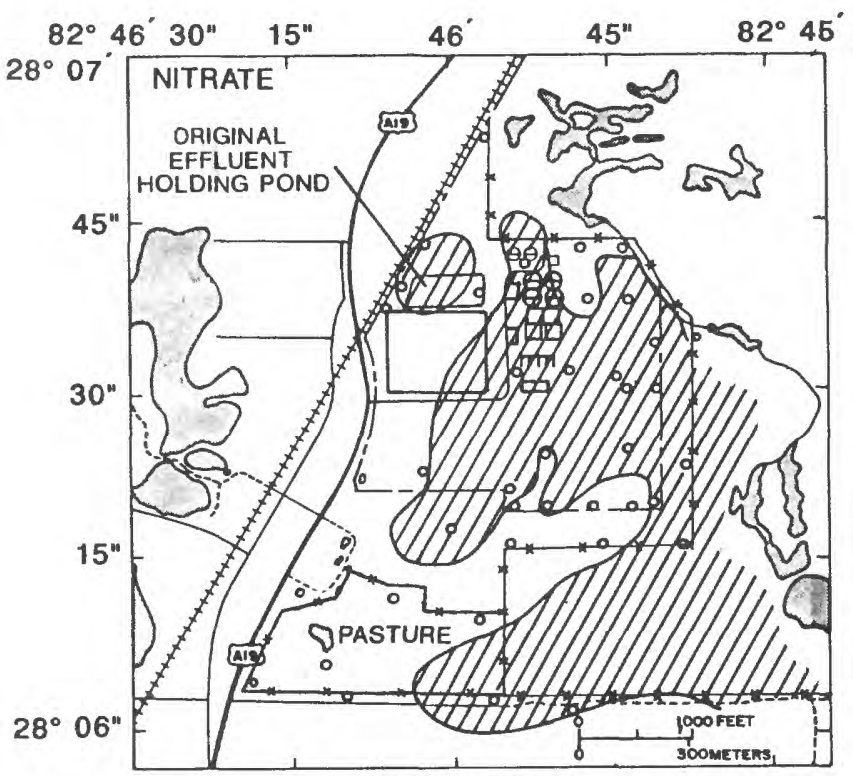

EXPLANATION

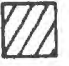

AREA CONTAINING NITRATE NITROGEN-In concentrations greater than 10 milligrams per liter

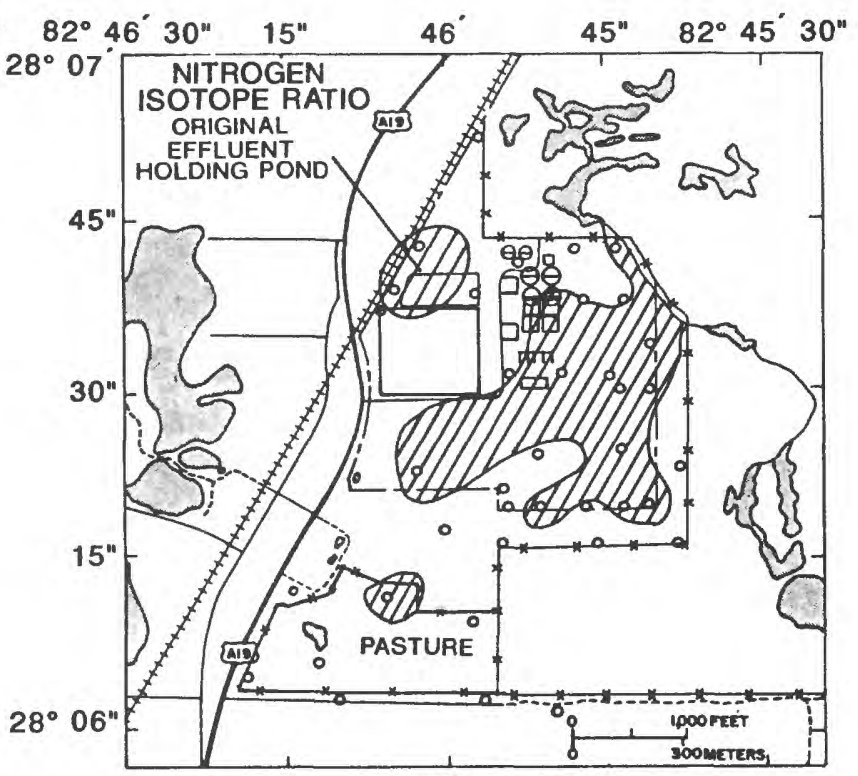

EXPLANATION

AREA CONTAINING NITROGEN ISOTOPE--

Ratio greater than +10 parts per thousand

- DATA-COLLECTION SITE

- data-Collection site

Figure 16. Distribution of nitrate-nitrogen concentration and the nitrogen isotope ratio in water from the surficial aquifer, March and April 1989. 


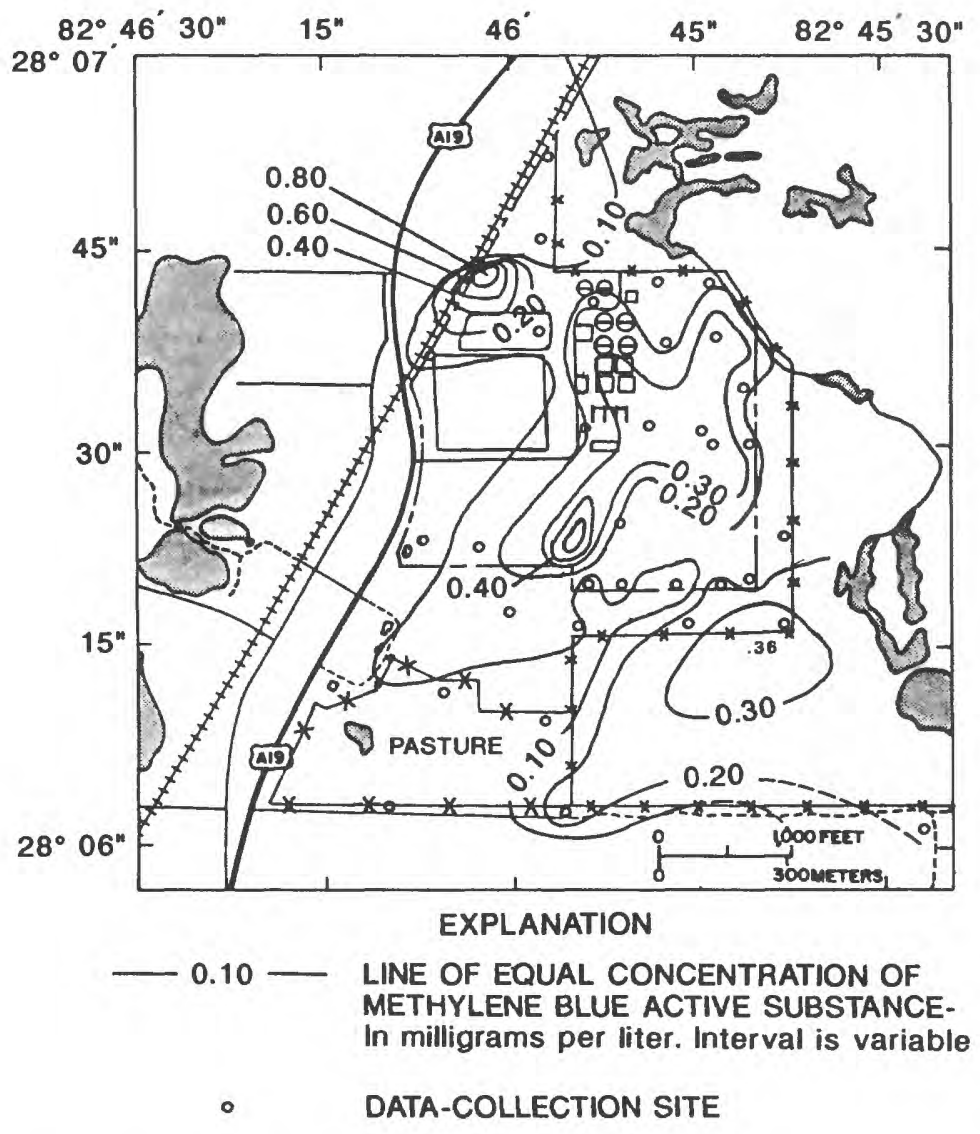

Figure 17. Distribution of methylene blue active substance in water from the surficial aquifer, March and April 1989.

course are fertilized twice a year at a rate of $200 \mathrm{lb} / \mathrm{acre}$. The amount of nitrogen applied annually to the golf course from fertilizer is about $200 \mathrm{lb} / \mathrm{acre}$. The annual total nitrogen load to the golf course from sprayed effluent is also about 200 $\mathrm{lb} / \mathrm{acre}$. The low $\delta^{15} \mathrm{~N}$ in the ground water is probably due to the mixing of the two nitrogen sources. As a result, groundwater samples contain $\delta^{15} \mathrm{~N}$ values between the ranges expected for the two major sources of nitrogen. Because the sandy soil in the area has a low organic content, the range of $\delta^{15} \mathrm{~N}$ values indicates a combination of fertilizer and effluent application is the probable source of the high nitrate concentrations in this part of the study area.

Dissolved phosphorus concentrations in the study area ranged from less than 0.02 to $6.1 \mathrm{mg} / \mathrm{L}$. Concentrations greater than $1.0 \mathrm{mg} / \mathrm{L}$ were found only in the immediate area of the sprayfield and in the area of the old sludge drying beds. The areal distribution of phosphorus (as P) was not as extensive as the distribution of other water-quality constituents. The limited distribution is due to plant uptake and the adsorption capabilities of the surficial deposits at the site. The capacity of the surficial deposits to adsorb phosphorus have been exceeded in the areas of heavy effluent or sludge disposal, allowing phosphorous to reach the water table.

The distribution pattern of MBAS in the surficial aquifer is similar to that of other conservative water-quality constituents (fig. 17). As with nitrate, the highest concentrations occurred at well sites 30 and 62 (fig. 1) in areas previously used to dry sludge. Water samples from sites 30 and 62 contained 0.61 and $1.8 \mathrm{mg} / \mathrm{L}$ of MBAS, respectively.

\section{Distribution of Water-Quality Constituents in the Upper Floridan Aquifer}

Water-quality samples also were collected from Wall Springs and from 21 Upper Floridan aquifer wells during March and April 1989 to determine if the aquifer had been affected by disposal operations. Major ion, nutrient, MBAS, and stable nitrogen isotope analyses were made on these samples. Results of the analyses are listed in table 8. 
Table 8. Summary of selected water-quality data for sites in the Upper Floridan aquifer, March and April 1989

IConcentrations are in milligrams per liter, except as noted. $\mu \mathrm{S} / \mathrm{cm}$, microsiemens per centimeter; MBAS, methylene blue active substance; ppt, parts per thousand; - , no data; <, less than]

\begin{tabular}{|c|c|c|c|c|c|c|c|c|c|c|c|c|c|c|}
\hline $\begin{array}{l}\text { Map } \\
\text { No. }{ }^{1}\end{array}$ & $\begin{array}{c}\text { Specific } \\
\text { conductance } \\
(\mu \mathrm{S} / \mathrm{cm})\end{array}$ & $\begin{array}{c}\mathrm{pH} \\
\text { (units) }\end{array}$ & $\begin{array}{c}\text { Ammonia } \\
\text { nitrogen } \\
\text { (as N) }\end{array}$ & $\begin{array}{c}\text { Nitrate } \\
\text { nitrogen } \\
(\operatorname{as~} N \text { ) }\end{array}$ & $\begin{array}{l}\delta^{15} N \\
(\mathrm{ppt})\end{array}$ & $\begin{array}{c}\text { Total } \\
\text { phosporus } \\
\text { (as P) }\end{array}$ & $\begin{array}{l}\text { Calcium } \\
\text { (dis- } \\
\text { solved) }\end{array}$ & $\begin{array}{l}\text { Magnesium } \\
\text { (dis- } \\
\text { solved) }\end{array}$ & $\begin{array}{l}\text { Sodium } \\
\text { (dis- } \\
\text { solved) }\end{array}$ & $\begin{array}{l}\text { Potassium } \\
\text { (dis- } \\
\text { solved) }\end{array}$ & $\begin{array}{l}\text { Alka- } \\
\text { linity }\end{array}$ & $\begin{array}{l}\text { Chloride } \\
\text { (dis- } \\
\text { solved) }\end{array}$ & $\begin{array}{c}\text { Sulfate } \\
\text { (dis- } \\
\text { solved) }\end{array}$ & MBAS \\
\hline 1 & 1,720 & 7.2 & 0.07 & 11 & 11.5 & 0.35 & 82 & 24 & 220 & 15 & 198 & 350 & 79 & 0.23 \\
\hline 2 & 909 & 7.7 & .01 & 1.7 & 9.9 & .03 & 56 & 14 & 98 & 4.3 & 126 & 180 & 33 & .10 \\
\hline 3 & 2,490 & 7.6 & $<.01$ & 5.7 & 7.2 & $<.02$ & 94 & 28 & 380 & 8.2 & 108 & 660 & 120 & .22 \\
\hline 9 & 508 & 7.4 & .04 & $<.01$ & - & .14 & 90 & 6.1 & 5.1 & 1.3 & 241 & 12 & 5.9 & .08 \\
\hline 12 & 1,030 & - & .04 & 6.9 & 3.9 & .27 & 49 & 1.5 & 120 & 15 & 42 & 180 & 65 & .07 \\
\hline 15 & 441 & 7.3 & $<.01$ & 5.7 & 12.9 & .57 & 64 & 2.8 & 21 & 3.5 & 151 & 27 & 25 & .05 \\
\hline${ }^{2} 19$ & 952 & 7.6 & $<.01$ & 13 & 16.3 & .14 & 62 & 16 & 110 & 10 & 166 & 130 & 75 & .20 \\
\hline${ }^{3} 19$ & 7,200 & 7.5 & .07 & .33 & - & .08 & 100 & 140 & 1,200 & 46 & 160 & 2,200 & 390 & - \\
\hline${ }^{4} 19$ & 11.500 & 7.5 & 4 & $<.02$ & - & .30 & 120 & 220 & 2,100 & 76 & 188 & 3.700 & 480 & .54 \\
\hline 21 & 603 & 7.7 & $<.01$ & 11 & 5.8 & .23 & 51 & 13 & 40 & 8.6 & 116 & 59 & 54 & .12 \\
\hline${ }^{5} 24$ & 1,060 & 7.6 & $<.01$ & 3.1 & - & .04 & 57 & 21 & 110 & 9.3 & 139 & 210 & 56 & .08 \\
\hline $6_{24}$ & 1,760 & 7.6 & $<.01$ & 6.2 & 12.9 & .05 & 60 & 33 & 240 & 15 & 156 & 400 & 90 & .08 \\
\hline 26 & 821 & 7.3 & $<.01$ & 8.5 & 11.9 & .15 & 71 & 9 & 76 & 8.5 & 155 & 110 & 54 & .02 \\
\hline 28 & 764 & 7.0 & .05 & .02 & 12.3 & .12 & 130 & 6.2 & 20 & 1.5 & 338 & 44 & 14 & .05 \\
\hline 32 & 276 & 7.8 & $<.01$ & .14 & - & .03 & 41 & 4 & 8.1 & 14 & 112 & 15 & 13 & .02 \\
\hline 38 & 975 & 7.4 & 10 & $<.02$ & - & 2.8 & 74 & 7 & 120 & 28 & 250 & 170 & 16 & - \\
\hline 39 & 1,010 & 7.3 & $<.01$ & 11 & 10 & .88 & 74 & 6 & 110 & 15 & 202 & 150 & 33 & .14 \\
\hline 41 & 798 & 7.4 & $<.01$ & 10 & 11.6 & .17 & 58 & 11 & 86 & 5.7 & 180 & 97 & 45 & .08 \\
\hline 45 & 4,350 & 7.5 & .15 & $<.02$ & - & .12 & 100 & 75 & 690 & 24 & 198 & 1,200 & 200 & .31 \\
\hline 46 & 998 & 7.1 & .01 & 1.7 & 26.5 & .13 & 120 & 6.7 & 84 & 3 & 293 & 130 & 33 & .13 \\
\hline 50 & 651 & 7.3 & $<.01$ & 4.9 & 15.3 & .04 & 69 & 16 & 39 & 2.6 & 197 & 69 & 21 & .08 \\
\hline 55 & 1,140 & 7.1 & .12 & 18 & 9.2 & 2.9 & 94 & 6.3 & 120 & 22 & 239 & 140 & 34 & .11 \\
\hline 60 & 995 & 7.2 & .45 & $<.01$ & - & .22 & 76 & 13 & 100 & 6.1 & 239 & 150 & 29 & .10 \\
\hline 64 & 429 & 7.5 & $<.01$ & 1.8 & 11.2 & .06 & 62 & 5.9 & 20 & 1.3 & 155 & 27 & 20 & .06 \\
\hline 65 & 536 & 7.5 & .08 & .05 & - & .08 & 55 & 2.8 & 48 & 1.2 & 136 & 69 & 28 & .05 \\
\hline
\end{tabular}

${ }^{1}$ Locations of sites are shown in figure 2.

${ }^{2}$ Sample was collected at a depth of $65 \mathrm{ft}$ below land surface.

${ }^{3}$ Sample was collected at a depth of $80 \mathrm{ft}$ below land surface.
${ }^{4}$ Sample was collected at a depth of $91 \mathrm{ft}$ below land surface.

${ }^{5}$ Sample was collected at a depth of $38 \mathrm{ft}$ below land surface.

${ }^{6}$ Sample was collected at a depth of $58 \mathrm{ft}$ below land surface.
Because the study area is underlain by saltwater at relatively shallow depths (about $150 \mathrm{ft}$ below land surface) and both saltwater and effluent have high concentrations of sodium and chloride and high specific-conductance values, the source of the high concentrations could not be directly identified by plotting the areal distributions. Different water types, however, could be identified by plotting major cation and anion equivalent concentration percentages on a trilinear diagram (fig. 18). The seawater plot on the trilinear diagram represents the results of a major ion analysis of a waterquality sample collected from the Gulf of Mexico in 1988 as part of a previous project.

Water quality in the sampled wells varied considerably, ranging from freshwater, typical of a shallow carbonate aquifer, to water affected by saltwater, or to effluent. An Upper Floridan aquifer well at site 9 (fig. 2) contained the freshest water in the study area. The well at site 9 is upgradient from the disposal site and is open only to the first $10 \mathrm{ft}$ of the aquifer. As a result, the well is not affected by effluent disposal at the sprayfield or by saltwater. However, detectable levels of MBAS in this well indicate that it is probably being affected by sewage leaching from septic tanks at private residences along Bee Pond Road that are upgradient of the well (figs. 1 and 11). Conversely, a sample from the irrigation well at site 19. collected from a depth of $91 \mathrm{ft}$ ( $19 \mathrm{~b}$ on the trilinear diagram), has a specific-conductance value of $11,480 \mu \mathrm{S} / \mathrm{cm}$. The equivalent concentration percentages for water from this well plot closer to those of seawater (fig. 18) than do the percentages for other Upper Floridan aquifer wells sampled in the study area.

The saltwater-freshwater interface, represented by the $19,000-\mathrm{mg} / \mathrm{L}$ chloride concentration, is approximately $250 \mathrm{ft}$ below land surface at the disposal site (Hickey, 1982. p. 29). Most water analyses plotted on the trilinear diagram lie along a mixing line between freshwater and seawater analyses (fig. 18), indicating variable amounts of mixing between the two water types. Effluent samples, when plotted on the trilinear diagram, are distinct enough to separate them from freshwater and 
seawater analyses. Samples from sites 1, 19 (collected from a depth of $91 \mathrm{ft}$ ), and 45 plot along a mixing line between the effluent and seawater analyses, indicating mixing of effluent with the deeper, more saline water underlying the study area. Analyses of samples from these wells plot closer to the seawater analysis than to effluent analyses, suggesting water quality in these wells is influenced more by the underlying saltwater than by effluent.

A second, shallower sample was collected at site 19 from a depth of $65 \mathrm{ft}$ (19a on the trilinear diagram). Specific conductance of the sample was $952 \mu \mathrm{S} / \mathrm{cm}$, more than an order of magnitude lower than the deeper sample. Equivalent concentration percentages for this analysis plot between the freshwater, saltwater, and effluent analyses. Water quality at this depth shows more mixing with effluent than with saltwater. Analyses of samples from the remaining wells plot between the two mixing lines, which indicates varying degrees of mixing between the three water types.

A vertical profile of water-quality samples collected from the Upper Floridan aquifer well at site 19 indicates fresher, effluent-like water occurs to a depth of $75 \mathrm{ft}$, and water affected by saltwater occurs at depths greater than $91 \mathrm{ft}$, suggesting stratification of water types in the aquifer (fig. 19). Specific-conductance values at a depth of $65 \mathrm{ft}$ were near $1,000 \mu \mathrm{S} / \mathrm{cm}$. Within a small transition zone (between 75 and $85 \mathrm{ft}$ ), specific-conductance values rose to more than $10,000 \mu \mathrm{S} / \mathrm{cm}$ and remained at that level to the bottom of the well. The stratified distribution of specific-conductance values in the well bore remained fairly consistent throughout the study period (1987-90), except for a slight variation that resulted from seasonal changes in the potentiometric surface of the aquifer.

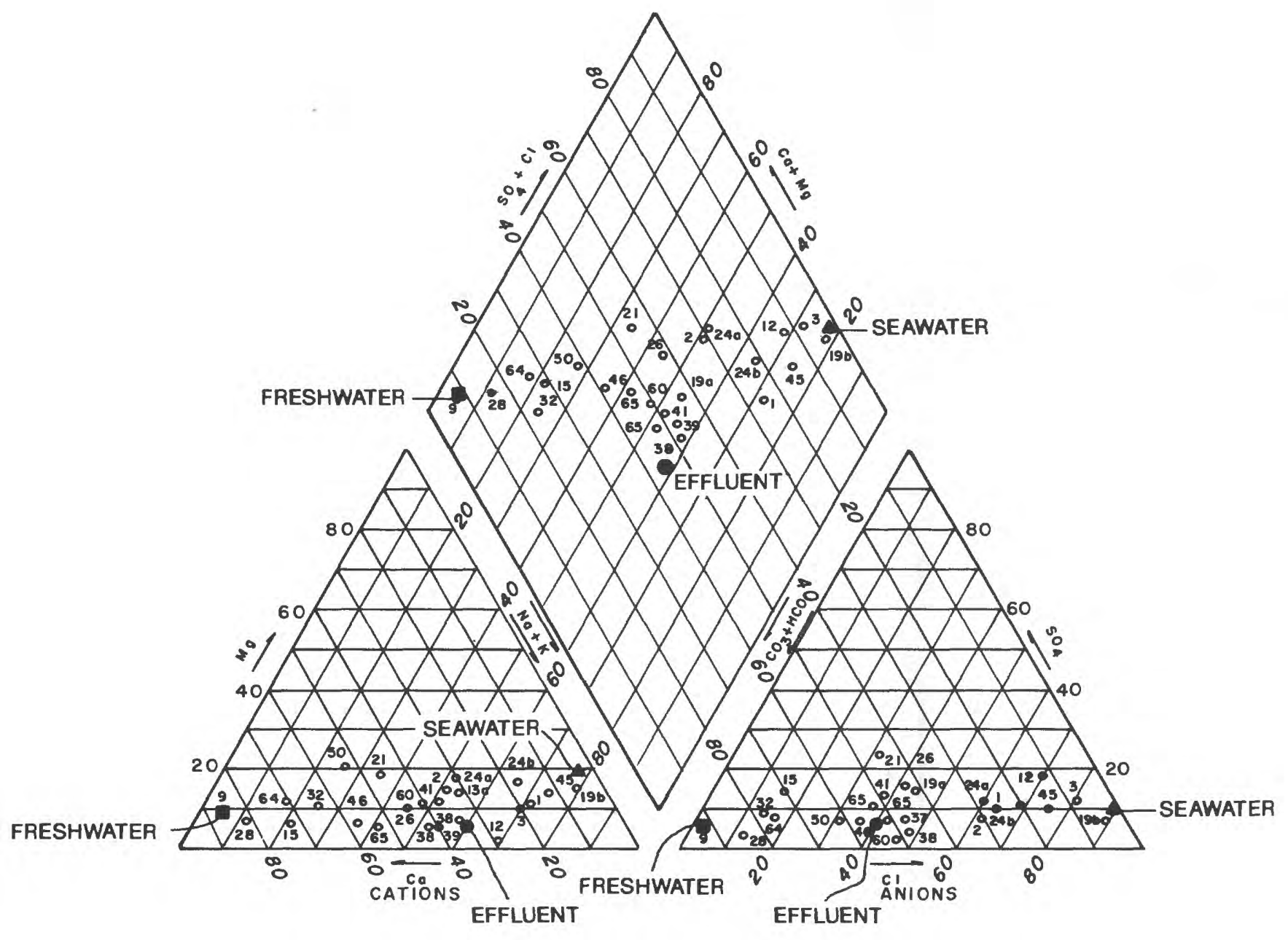

EQUIVALENT CONCENTRATION PERCENTAGES

Figure 18. Major cation and anion equivalent concentration percentages. 

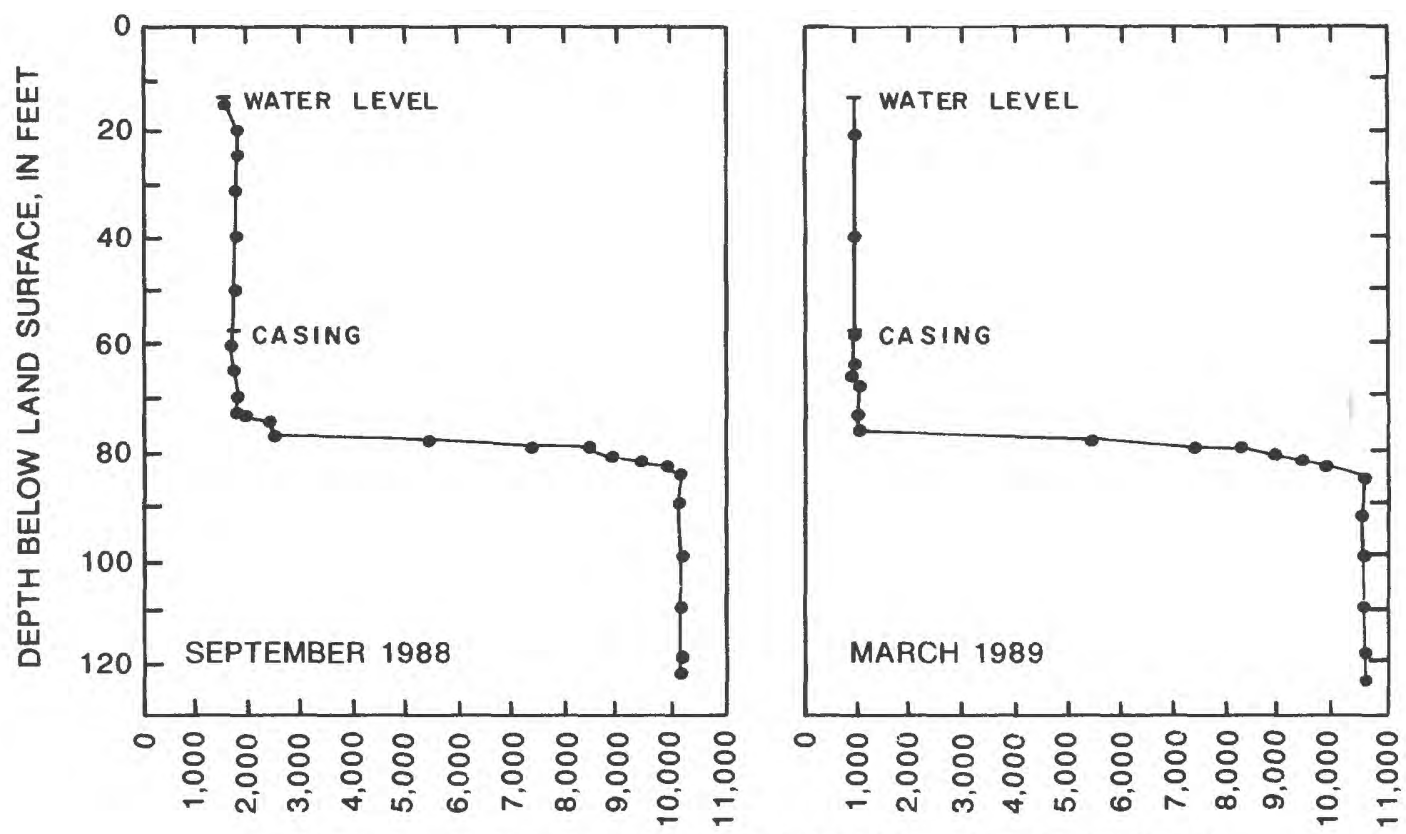

SPECIFIC CONDUCTANCE, IN MICROSIEMENS PER CENTIMETER

Figure 19. Conductivity profile of water in the Upper Floridan aquifer well at site 19, September 1988 and March 1989.

Stratification of water types also was observed in the Upper Floridan aquifer well at site 24 (fig. 2). The well at site 24 is closer to the coast (about $1,000 \mathrm{ft}$ west of site 19). Specific-conductance values increase with depth during the dry season when effluent disposal, upgradient from the well site, is minimal and the potentiometric surface of the aquifer is low. Specific-conductance values at the site during May 1988 were about $1,000 \mu \mathrm{S} / \mathrm{cm}$ at a depth of $35 \mathrm{ft}, 3,000$ $\mu \mathrm{S} / \mathrm{cm}$ at $40 \mathrm{ft}$, and about $7,000 \mu \mathrm{S} / \mathrm{cm}$ below $50 \mathrm{ft}$. During the wet season when the heaviest disposal occurs at the sprayfield and the potentiometric surface is high, water in the entire well bore is relatively fresh, with specific-conductance values averaging about $1,000 \mu \mathrm{S} / \mathrm{cm}$. Because this well is only $65 \mathrm{ft}$ deep, stratification is evident only when the potentiometric surface is low.

The wells at sites 19 and 24 are the only Upper Floridan aquifer wells in the study area that are deep enough and have a large enough open-hole section to observe the stratification of water types. Stratification probably occurs along the entire coastal margin in the study area.

In the study area, the dominant species of nitrogen in the Upper Floridan aquifer is nitrate. Concentrations range from less than 0.1 to about $18.0 \mathrm{mg} / \mathrm{L}$. Nitrate-nitrogen concentrations in the Upper Floridan aquifer exceed the drinking water standard of $10 \mathrm{mg} / \mathrm{L}$ established by the Florida Department of Environmental Regulation (1989) in the area of the disposal site and in the area of the grove (fig. 20), extending southwesterly from well site 55 (fig. 2) toward the ground-water trough and then westerly along a narrow band around Wall Springs. A sample collected during February 1989 from site 21 (fig. 2) contained $11.0 \mathrm{mg} / \mathrm{L}$ of nitrate nitrogen, which exceeds drinking water standards. Nitratenitrogen concentrations in Wall Springs have consistently exceeded $10 \mathrm{mg} / \mathrm{L}$ since August 1988.

The distribution of ${ }^{15} \mathrm{~N}$-enriched water is more widespread in the Upper Floridan aquifer (fig. 20) than is the distribution of water that contains nitrate concentrations greater than $10 \mathrm{mg} / \mathrm{L}$. With the exception of the well at site 21 , the $\delta^{15} \mathrm{~N}$ values were greater than $+10 \mathrm{ppt}$ in the entire area that extends from the disposal site westward toward the coast. The area containing high $\delta^{15} \mathrm{~N}$ values includes sites that have nitrate concentrations of less than $10 \mathrm{mg} / \mathrm{L}$. The high nitrogen concentrations in the water flowing from Wall Springs (fig. 2, site 1) and in the Upper Floridan aquifer in this area apparently originate from the effluent.

The private supply well at site 21 is in the trough area and contains a high concentration of nitrate $(11.0 \mathrm{mg} / \mathrm{L})$, but the $\delta^{15} \mathrm{~N}$ value is low $(5.8 \mathrm{ppt})$, indicating an additional source other than effluent, possibly fertilizer applied in the vicinity of the well. However, the Upper Floridan aquifer wells at sites 19 and 24, located in the grove, showed no indication of a fertilizer source. Conversely, they contained nitrates with $\delta^{15} \mathrm{~N}$ values greater than $10 \mathrm{ppt}$, which are indicative of effluent. Both grove wells also are 
within the ground-water trough. Unlike most other Upper Floridan aquifer wells in the area, the direction of groundwater flow in the vicinity of site 21 varies with changes in the potentiometric surface of the aquifer. Flow past the well is northerly when water levels are high and westerly when levels are low (fig. 10). Water-quality in the well at site 21 is more likely to be affected by disposal operations during periods of low water.

Areas that contain high nitrate concentrations and correspondingly low $\delta^{15} \mathrm{~N}$ values, indicating fertilizer sources of nitrate similar to those in the surficial aquifer underlying the golf course, were not observed in the Upper Floridan aquifer. Nitrate from fertilizer used at the golf course apparently has not reached the Upper Floridan aquifer, probably due to a more continuous residuum layer underlying the golf course. High nitrate concentrations in the Upper Floridan aquifer at and west of the disposal site appear to be a result of effluent disposal.

Phosphorus concentrations were similar to predisposal levels at most sites. Samples from only two wells (sites 38 and 55) at the sprayfield contained phosphorus concentrations greater than $2 \mathrm{mg} / \mathrm{L}$. Concentrations in the Upper Floridan aquifer ranged from 0.02 to $2.9 \mathrm{mg} / \mathrm{L}$. The area of high phosphorus concentration in the Upper Floridan aquifer underlies a similar area of high concentration in the surficial aquifer. Drilling records for site 55 and the occurrence of a

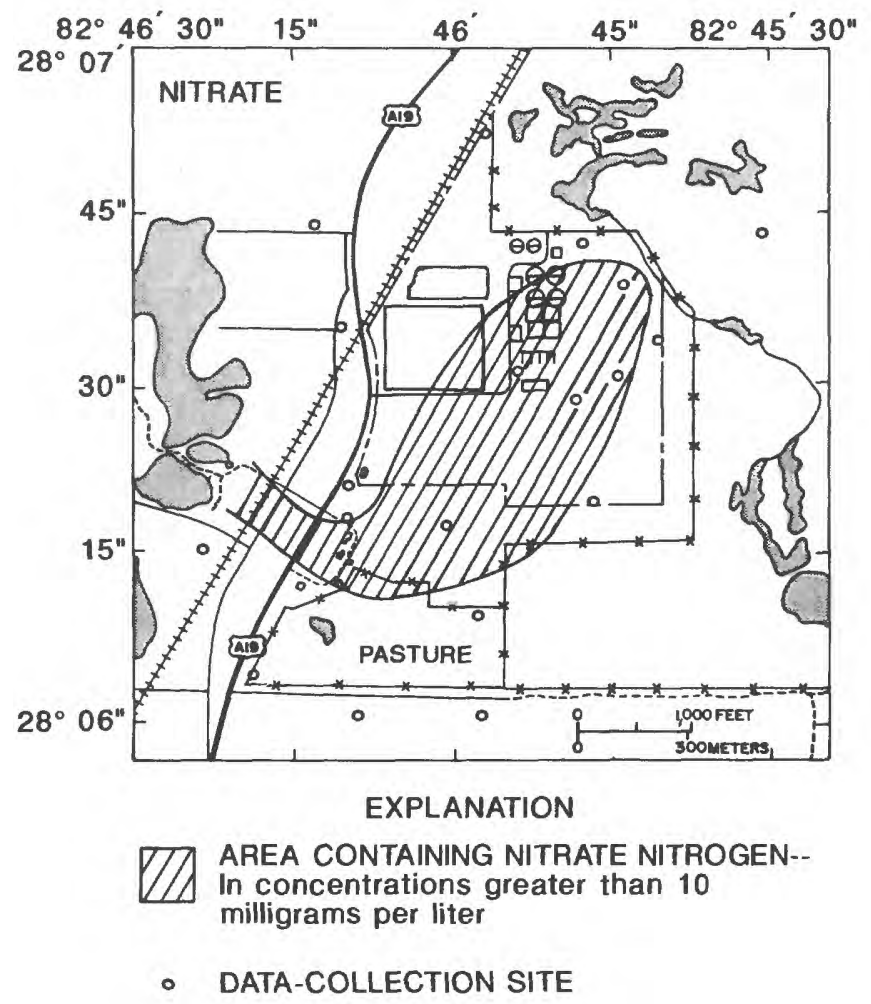

large sinkhole (March 1988) adjacent to site 38 indicate the residuum is thin and discontinuous in this area, allowing water to move rapidly from the surficial deposits to the Upper Floridan aquifer. The high phosphorus concentration may be explained by a short residence time of the water in these deposits before it enters the Upper Floridan aquifer. The limited distribution of phosphorus in the Upper Floridan aquifer is probably due to the ability of materials in the aquifer to adsorb phosphorus.

Distribution of MBAS in water in the Upper Floridan aquifer closely resembles the distribution of nitrogen (fig. 21). Concentrations of MBAS ranged between 0.02 and $0.54 \mathrm{mg} / \mathrm{L}$, with the highest concentrations detected in the central part of the study area along a line between well sites 19 and 45 (fig. 2). The sample from the well at site 19 contained $0.54 \mathrm{mg} / \mathrm{L}$ of MBAS, the highest concentration detected in the Upper Floridan aquifer at the study site.

Water-quality problems have been reported in private supply wells along Bee Pond Road, south of the disposal site (fig. 2). Samples have been collected periodically from the wells at sites 2 and 3 since 1978 and have had a consistent pattern of high major ion concentrations and low nutrient concentrations. This pattern indicates a source other than sewage effluent is probably the cause of the water-quality problems. The trilinear plot of ion equivalent concentration percentages (fig. 18, sites 2 and 3 ) indicates that these wells

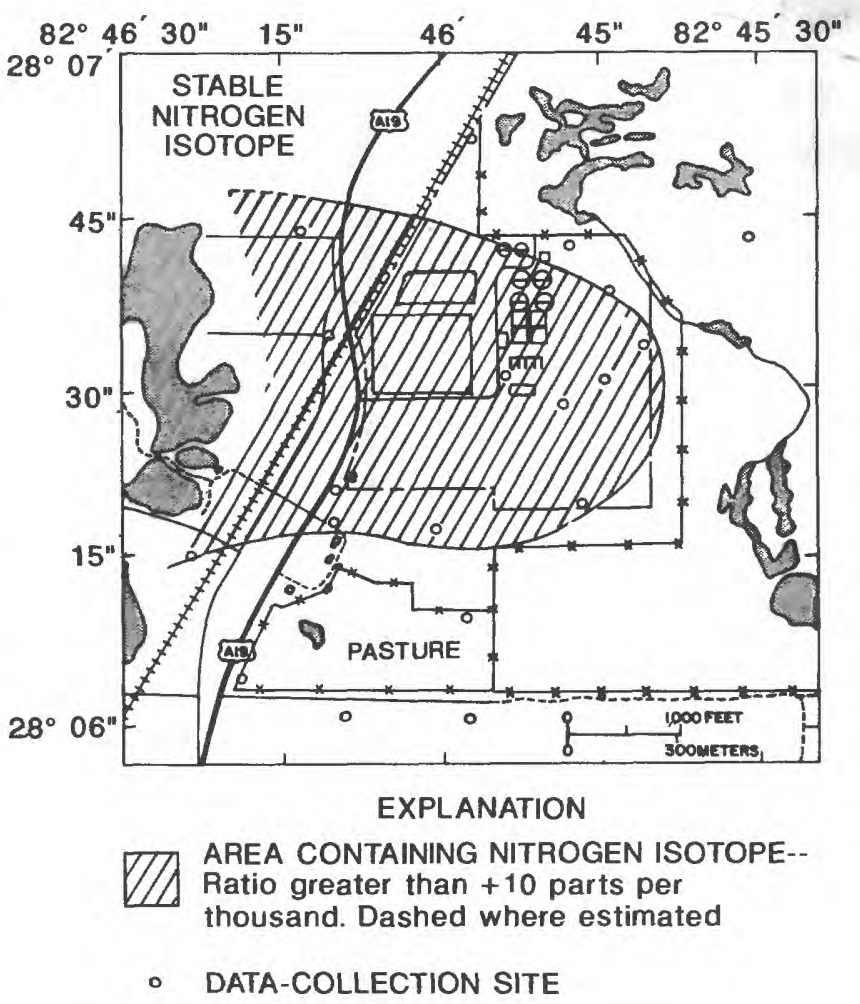

Figure 20. Distribution of nitrate-nitrogen concentration and the nitrogen isotope ratio in water from the Upper Floridan aquifer, March and April 1989. 
probably are influenced by saltwater. Ground-water flow patterns indicate that these wells are upgradient from the disposal site and should not be affected by disposal operations.

The configuration of the potentiometric surface of the Upper Floridan aquifer (fig. 10) and the narrow distribution of high nitrate and MBAS concentrations (figs. 20 and 21) through the area of the ground-water trough toward Wall Springs indicates channelization of flow through this area. Drilling activities and GPR surveys have indicated discontinuity in the residuum and a probable high degree of secondary porosity in the underlying limestone. The high permeability resulting from the high secondary porosity between the disposal site and Wall Springs allows the effluent that reaches the Upper Floridan aquifer to be diluted and to move rapidly away from the disposal site toward discharge points at the coast. If secondary porosity in the limestone in the area of the trough were not as developed as it is, the distribution of nitrate concentrations in the ground water might be more widespread.

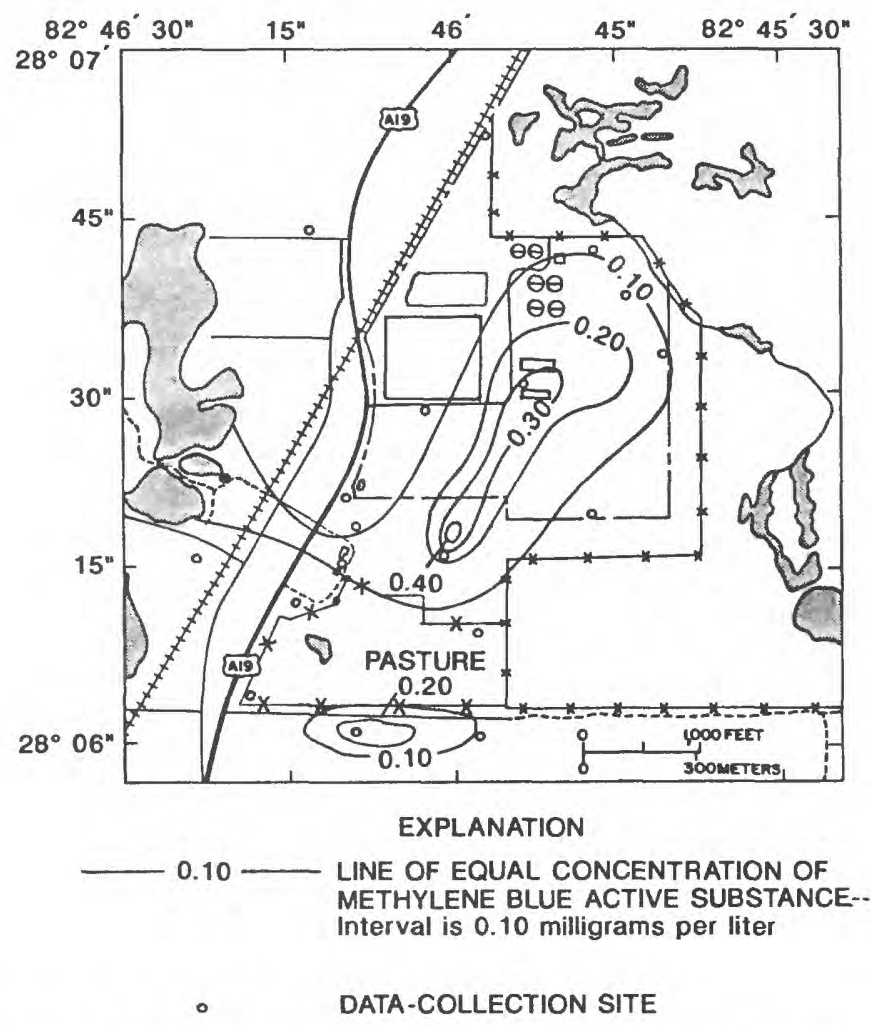

Figure 21. Distribution of methylene blue active substance in water from the Upper Floridan aquifer, March and April 1989.

\section{SUMMARY AND CONCLUSIONS}

The effects of municipal effluent and sludge disposal on the ground water at a $1-\mathrm{mi}^{2}$ coastal site in northwestern Pinellas County were investigated from 1986 to 1990; disposal has occurred at this site since 1976. The site is in a sand dune ridge area where land-surface elevations range from sea level to about $65 \mathrm{ft}$ above sea level. Drainage at the disposal site is internal.

Test drilling and ground-penetrating-radar surveys were used to define the hydrogeologic framework at the study area. The thickness of the surficial sand ranges from 5 to $50 \mathrm{ft}$; however, thickness of the saturated zone in the surficial sand ranges from less than $1 \mathrm{ft}$ to about $15 \mathrm{ft}$. A thin, discontinuous, clayey residuum separates the surficial sand from the underlying limestone, forming a leaky semiconfining unit. The residuum pinches out west of the disposal site near the coast. The surface of the residuum is irregular and is breached in many places by sand-filled karst features. The surface of the residuum reflects the irregular surface of the underlying limestone. A high degree of secondary porosity appears to have developed in the limestone, particularly west and southwest of the disposal site around Wall Springs and in the area of a citrus grove.

Two ground-water troughs existed in the surficial aquifer prior to disposal operations. One was under a resort drainage ditch and reflected ground water discharging to the ditch from the surficial aquifer. A larger trough extended from the coast, through the central part of the disposal site, to the resort. Discharge in this area was to the underlying Upper Floridan aquifer. The troughs persisted in the surficial aquifer under disposal conditions; however, the larger trough is not as extensive. A potentiometric-surface trough was mapped in the Upper Floridan aquifer, underlying the same area as the large trough in the surficial aquifer. The trough possibly represents an area of increased transmissivity.

Because good interaquifer connection exists, disposal operations have resulted in a mound in both aquifers. The mound in the surficial aquifer underlies the disposal site and the golf course to the south. Water levels in the mound area range from $4 \mathrm{ft}$ to more than $6 \mathrm{ft}$ higher than water levels in surrounding areas. The mound was present in the surficial aquifer during the entire study period. When effluent disposal is heavy and water levels in the surficial aquifer under the site are high, a potentiometric-surface mound also is present in the Upper Floridan aquifer. A similar mound is not present under the golf course. During dry periods when effluent is diverted to the golf course and the adjacent resort and water levels in the surficial aquifer under the disposal site drop, the mound in the Upper Floridan aquifer is almost nonexistent. When the mound is present in the Upper Floridan aquifer, water levels in affected wells are about $1 \mathrm{ft}$ higher than those in surrounding areas.

At the disposal site, ground water in the surficial aquifer flows northeasterly from the ground-water mound toward the ditch and southwesterly toward the trough in the central part of the study area. Flow in the southern part of the study area is from that part of the mound that underlies the golf course west and northwesterly toward the central trough. Flow in the Upper Floridan aquifer is generally east to west through the study area; however, the ground-water trough and mound 
alter the direction. When little or no mounding occurs in the Upper Floridan aquifer, water flows into the study area from the east, converging toward the trough, then westward toward discharge points along the coast. When mounding occurs, flow moves radially away from the mound. Water entering from the east is diverted, moving westerly around the mound to the north, and converges toward the trough to the south.

Concentrations of various chemical constituents in the surficial aquifer were higher in areas that receive effluent and lower in areas that correspond to the ground-water trough. The occurrence of $\delta^{15} \mathrm{~N}$ values greater than +10 parts per thousand in water indicates effluent may be the source of the high nitrate concentrations in the surficial aquifer at the site. Fertilizer is another source of high nitrate concentrations in the ground water under the golf course. At two locations within the disposal site, the surficial aquifer contained water with major ion concentrations higher than those in the effluent. Both locations are on the edge of the former sludge-drying beds. Nitrate is the only constituent that exceeds allowable limits for drinking water in the study area. Distribution of phosphorus in the surficial aquifer is restricted because vegetation at the site and materials within the surficial deposits cause phosphorus to be adsorbed or precipitated from solution.

Water in the Upper Floridan aquifer ranges from freshwater to water similar in character to saltwater, or to effluent. Most wells sampled had water representing varying degrees of mixing between water types. Nitrate-nitrogen concentrations exceeded drinking water standards in areas upgradient from private supply wells. Water with nitratenitrogen concentrations greater than $10 \mathrm{mg} / \mathrm{L}$ underlies the disposal site and extends through the potentiometric-surface trough to the coast near Wall Springs. Water enriched with ${ }^{15} \mathrm{~N}$ flows from Wall Springs and is distributed throughout the area west of the disposal site. Water enriched with ${ }^{15} \mathrm{~N}$ occurs in areas containing both high and low nitrate concentrations. The exception to this is the private supply well at site 21 , which contained a high concentration of nitrate nitrogen, but low $\delta^{15} \mathrm{~N}$ values, indicating a nitrogen source other than or in addition to effluent. A small area of high phosphorus concentration is located in the Upper Floridan aquifer in the northern part of the disposal site. The area directly underlies a similar area of high phosphorus concentration in the surficial aquifer. Distribution of MBAS in the aquifer is similar to the nitrate distribution.

Wells along Bee Pond Road, south of the disposal site, are upgradient and are not affected by effluent disposal. Water quality in these wells is affected by saltwater.

The apparent high degree of secondary porosity in the area between the disposal site and Wall Springs allows effluent that reaches the Upper Floridan aquifer to move rapidly toward coastal discharge points. If secondary porosity had not so extensively developed in this area, distribution of effluent-affected ground water might be more widespread.

\section{SELECTED REFERENCES}

Brown, D.P., 1981, Effects of effluent spray irrigation on ground water at a test site near Tarpon Springs. Florida: U.S. Geological Survey Open-File Report 81-1197, 36 p.

Causseaux, K.W., 1985, The surficial aquifer system in Pinellas County, Florida: U.S. Geological Survey Water-Resources Investigations Report 84-4289, 26 p.

Cherry, R.N.. 1966. Chloride content of ground water in Pinellas County, Florida, in 1950 and 1963: Florida Division of Geology Map Series 20.

Cherry, R.N., Brown, D.P., Stamer, J.K., and Goetz, C.L., 1973, Hydrobiochemical effects of spraying waste-treatment effluent in St. Petersburg, Florida: Gainesville, Institute of Food and Agricultural Science, University of Florida, 21 p.

Dohrenwend, R.E., 1977, Evapotranspiration patterns in Florida: Florida Scientist, v. 40, no. 2, p. 184-192.

Florida Department of Environmental Regulation, 1989, Water-quality standards: Chapter 17-550, in Florida Administrative Code.

Heath, R.C., and Smith, P.C., 1954, Ground-water resources of Pinellas County, Florida: Florida Geological Survey Report of Investigations $12,139 \mathrm{p}$.

Hem, J.D., 1985, Study and interpretation of the chemical characteristics of natural water ( $3 \mathrm{~d}$ ed.): U.S. Geological Survey Water-Supply Paper 2254, 263 p.

Hickey, J.J., 1982, Hydrogeology and results of injection tests at waste-injection sites in Pinellas County, Florida: U.S. Geological Survey Water-Supply Paper 2183, 42 p.

Johnson, C.C., 1979, Land applications of waste-an accident waiting to happen: Ground water, v. 17, no. 1, p. 69-72.

Kreitler, C.W., 1975, Determining the source of nitrate in ground water by nitrogen isotope studies: Austin, University of Texas, Bureau of Economic Geology Report of Investigation 83, 57 p.

Kreitler, C.W.. Ragone, S.F.. and Katz. B.G.. 1978. ${ }^{15} \mathrm{~N} /{ }^{14} \mathrm{~N}$ ratios of ground water nitrate, Long Island, New York: Ground Water, v. 16 , no. 6, p. $404-409$.

McCarten. Lucy, Trommer, J.T., Owens. J.P., and Hawkins, R.M., 1992, Mineralogy of a sand-filled sinkhole complex in Pinellas County, Florida, in Gohn, G.S., ed., Proceedings of the 1988 U.S. Geological Survey Workshop on Geology and Geohydrology of the Atlantic Coastal Plain: U.S. Geological Survey Circular 1059.

Miller, J.A., 1986, Hydrogeologic framework of the Floridan aquifer system in Florida and parts of Georgia, South Carolina, and Alabama: U.S. Geological Survey Professional Paper 1403-B, 91 p.

National Oceanic and Atmospheric Administration. 1988, Climatological data, annual summary, Florida, 1988: v. 92, no. 13.

Nettles and Vandor, Inc., 1986, Hydrogeological investigation for the North Treatment Plant expansion: Determination of spray application rates and groundwater impacts (appendices C-1): Prepared for Pinellas County Board of County Commissioners, Pinellas County Sewer System.

Southeastern Geological Society, 1986, Hydrogeological units of Florida: Florida Geological Survey Special Publication 28, 9 p.

White, W.A., 1970. Geomorphology of the Florida Peninsula: Florida Bureau of Geology Bulletin 51, $164 \mathrm{p}$.

Wolansky, R.M., and Corral, M.A., Jr., 1985, Aquifer tests in west-central Florida, 1952-76: U.S. Geological Survey Water-Resources Investigations Report 84-4044, 127 p.

Wolansky, R.M., and Garbade, J.M., 1980, Generalized thickness of the Floridan aquifer, Southwest Florida Water Management District: U.S. Geological Survey Water-Resources Investigations Open-File Report 80-1288, I sheet. 